\title{
Financial Capability Formation and the Variables That Effect It with Respect to Canadian Consumers
}

\author{
Lingxao Su, Kritagya Dhanda \\ University of Windsor, Canada
}

\begin{abstract}
.
With the ascent of money, services provided in the financial systems of different economies have extended the hand of consumers on numerous commodities other than for current consumption but also for future consumption. It is a financially capable individual who is able to make informed financial decisions and understand the use and management of money. In this paper, we argue that not only the individual's income, education, and age are significant in predicting financial capability but also his or her financial literacy, tangible assets, retirement plans and even debts and liabilities. By construction of a scoring mechanism based on behavioral and quantitative responses in a cross-sectional survey, we found that thirty percent of the variation in the financial capability index is explained by the parameters whereas the household income was found to be an insignificant parameter.
\end{abstract}

Keywords: Behavioral, Education, Financial capability index, Financial Literacy, Financial management of money, Income, Quantitative.

\section{Introduction}

The decisions made by individuals in their day-to-day financial transactions and patterns of behavior of that decision making collectively molds future life cycle of individuals. From buying the best product available in the market, making timely budgets to making more significant transactions that affect long term life such as making down payments for houses, education loans, and retirement planning, require efforts from the individual to plan ahead of time of both short and long term financial transactions. This ability to make informed judgements and make effective decisions regarding the use and managements of money (Noctor et al. 1992) exclaims the financial capability of the individual or a consumer of financial services. There has been a wide array of studies on the financial capability of citizens of different countries. Financial capability has also been an engaging subject matter for government policies and banking institutions as financial literacy and gender has served as significant determinants of individual financial 
performance (Bahovec et al. 2017). In the domain of public policies, non-profit organizations and government agencies such as Basic

Skill Agency and Financial Services Authority in the United Kingdom in 2004 (Kempson et al. 2005) took an initiative for financial services regulations to promote better understanding and attitudes towards the financial system.

According to the National Foundation for Education Research, financially capable people are,

"able to make informed financial decisions. They are numerate and can budget and manage money effectively. They understand how to manage credit and debt.

They are able to assess needs for insurance and protection. They can assess the different risks and returns involved in different saving and investment options. They have an understanding of the wider ethical, social, political and environmental dimensions of finances."

Albeit the numerate abilities are not ideal to assume for everyone, but it elaborates the functionalities that a higher financially capable individual incorporates in buying and/or investing in goods and services other than of a financial nature. Attributes or elements of financial capability curtail firstly financial knowledge and understanding: the implication of this point does not attribute professional education but an overall understanding of money and its different forms, mediums, and their respective benefits that lead to the right choices for their needs. Thus, financial literacy serves as an integral part of financial capability. It can be defined as an individual's ability to obtain, understand and evaluate the relevant information necessary to make decisions with an awareness of the likely financial consequences (Mason and Wilson, 2000). Secondly, attributes include financial skills that are the application of knowledge and understanding predictable and unpredictable situations. Thirdly, financial responsibility towards one's family, retirement and/or education. Based on these elements, the Basic Skills Agency developed a framework for Adult Financial Capability that specified three levels of capability that are:

a. Basic understanding and developing confidence: Aimed at those adults who have a low level of understanding and who require the skills to make informed judgements concerning their finances and the ability to use appropriate financial services.

b. Developing competence and confidence: Aimed at those adults who have a basic understanding and competence in handling financial services and require more knowledge and skills to meet their needs.

c. Extending competence and confidence: Aimed at adults who require the skills and knowledge to understand the wider range of services and the ability to make informed decisions regarding their own personal circumstances. (Basic Skills Agency, 2004). 
It is, therefore, paramount for individuals to be financial capable to lead to financially healthy lives. This is ascertained through behavioral factors that influence the consumer at an individual level and by the market at a macro level. The main question arises on how to quantify the financial capability of an individual, what does it entail, and how does it interact with the individuals' demographics: income level, education, gender, age, household size, financial literacy but also the long term individuals belongings and planning such as investments, pensions, assets, debts and liabilities. The extension of calculating a score through the responses on qualitative and quantitative questions in the Financial Capability Survey, 2014 by Statistics Canada, we have tried to understand the relationship of the financial capability of the individual to the numerous assets, demographic and household data of the same said individuals. The financial capability index is also constructed with an approach of assigning scores to questions and adding them up to a total score that also credit risks taken in short run expenses to long term debts and liabilities that may assess the risk of an individual falling into arrears. In attempt to test this an econometric model is constructed and using Ordinary Least Squares estimation technique we have found that not only does personal income, age, gender and financial assets are significant variables effecting the financial capability but also tangible assets and registered retirement savings plans are significant variables in the estimation. This pertinently evaluates the typology of consumer financial capability that describes an individuals' strengths and weaknesses.

\section{Literature Review}

Scholars have measured and analyzed people's financial capability from different dimensions and aspects in different ways. First, different people have various abilities of finance based on whether they are financially literate or not (Buckland, 2010). This implies that people with higher financial literacy usually have higher financial abilities, financial knowledge and skills. They are richer than others, and their daily and longterm attitude towards maintaining or promoting personal finances is more positive and correct. While substantial literature suggests that financial literacy is often correlated with populations having higher income levels, educatively wealthy and specialized occupation jobholders, however, the low-income Canadians are found to be substantially aware of banking, government and local programs and services. More pertinent to this point was that low-income group individuals could have high financial literacy that means they have a good knowledge of finance, but they face other troubles like institutional factors or personal reasons such as declining wages, income security policies that create "welfare wall" would lead them to get a low income (Buckland, 2010). Besides that, a study in the United States: National Financial Capability Study

(NFCS) suggests that citizens' financial literacy shows an inverted U-shaped development trend with age. Noticeably, people who are facing retirement usually have weak financial capabilities due to lack of financial knowledge. With nearly forty percent retirees have more than two sources of debt and heavy credit card usage signals lack of understanding of extreme credit use and the intense level of financial stress and 
overburdening of debt during retirement. For example, older people's expense on financial activities like mortgage, credit card balance transfers and home equity loans have increased with age, but they usually pay the highest costs for their credit cards and loan services such as liquidated damages and penalties (Lusardi and Scheresberg, 2016).

Furthermore, Rothwell, Mohammad and Cherney (2016) tried to illustrate how to measure an individual's financial capability in two components including objective knowledge of finance and self-efficacy of finance. On the one hand, by using questionnaires to test an individual's understanding of finance could help scholars to know the level of financial knowledge of the respondent, on the other hand, researchers should also pay attention to people's assessments and expectations of their financial ability, which will help them better judge whether respondents are over confident or not. Moreover, Personal Finance Research Centre (2017) pointed out that there are some factors which affect financially capable individual's behavior and that it must include managing money with evaluation of present and future times, having a plan for retirement, making good preparation for life events and dealing with financial difficulties efficiently. In other words, this means that when assessing a person's financial ability, scholars should focus on whether people have good financial management sense, have good crisis response ability, and whether they will focus on long-term interests. Nicolini (2006) conducted a social survey in Europe and mentioned that scholars have access to measure individual's financial capability by 4 pillars including managing money, planning ahead, selecting and making good use of financial products, and accessing and looking for other people or the third parties help. Therefore, by using the Canadian financial capability survey (2014), we can get the factors of people's ability to finance which is relevant to their daily life and situations.

\section{Data}

\subsection{Financial Capability Survey}

Released by Statistics Canada in 2009 the Canadian Financial Capability Survey (CFCS) provided significant results of retirees and pre-retirees. This subjective assessment entailed a nationally representative survey that collected 15,519 respondents over 18 years of age or older living in private households over 10 provinces. Running multivariate regression with a specific categorical reference group with the response categories responses on one of the survey subject of financial situation which suggested results in the chart 1 (Schellenberg and Ostrovsky, 2010) indicates preferences of revenue sources for retirement amongst employees and selfemployed wherein the latter is consistent with other ways such as through nonregistered assets, inheritance, business assets. While employees have revenue sources from government retirement plans and workplace pension that is sixty eight percent of them, self-employed individuals tended to include a diverse range of revenue sources in their financial plans for retirement. 


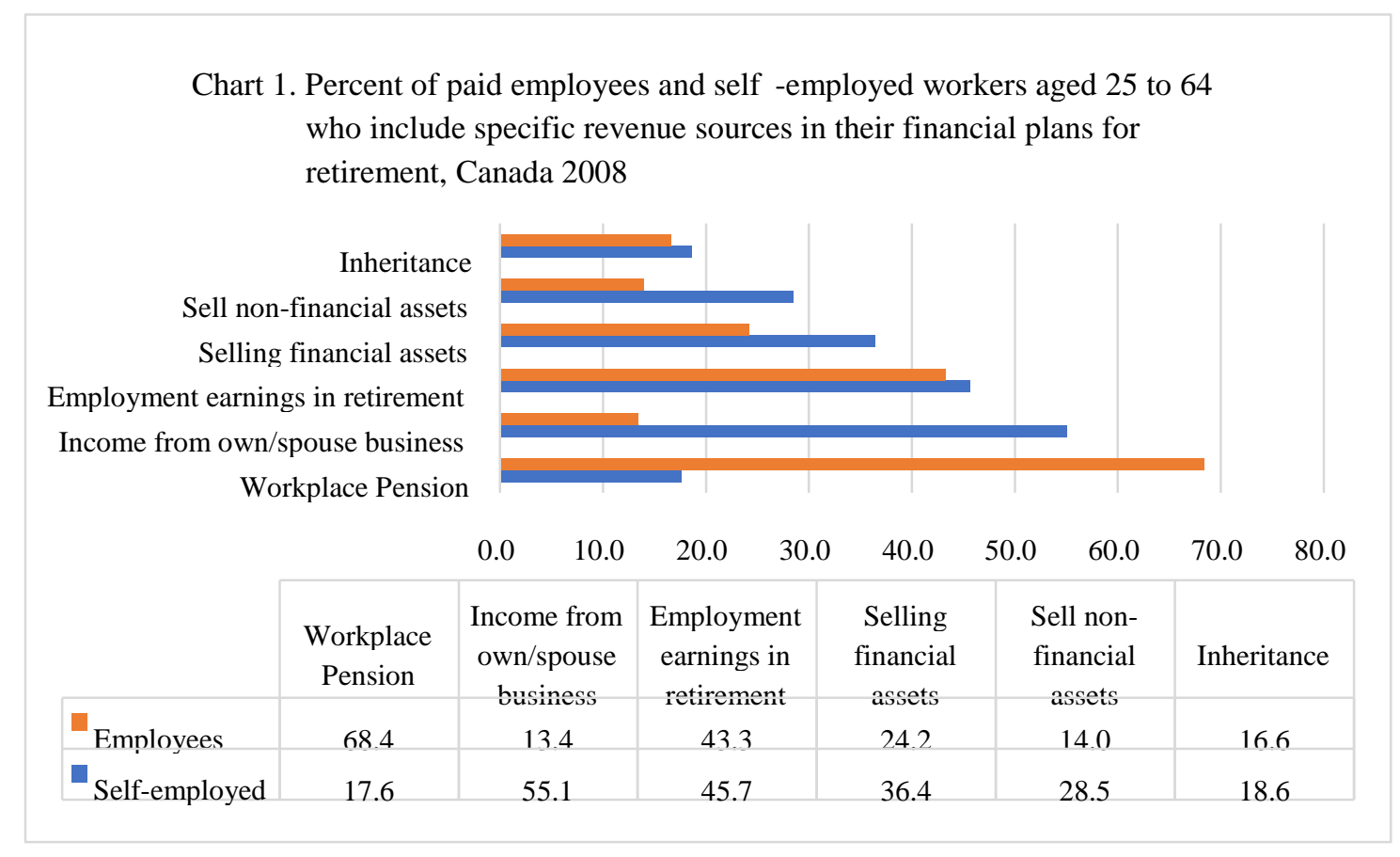

Source: Author's comnilation

\subsection{Financial Capability Index}

The essence of the index tells us the meagre good practices that one should follow in making financial transactions for current and future consumption. Such decision making essentially builds financial capability score of the individual. In consideration of micro aspects such as whether an individual looks at best priced and quality products while shopping around the market. If an individual's risk averse behavior helps in better decision making in everyday life and future decisions for family and assets. Moreover, having a credit card debt while not creating budgets or whether meeting budget constraints are a struggle condone a low financial capability of the individual irrespective of income levels. While responses recorded of choices of financial assets, mortgages, education, and understanding concepts of risk and insurance cater to foreshadowing life in certain and uncertain times. An intriguing qualitative parameter of confidence of an individual also plays a critical role in building the financial capability of an individual. This can be elaborated with junctures of self-evaluation of the respondent of how confident they are to analyze their financial decision making and whether they take steps further to build knowledge through advice from difference sources on ongoing-pending decisions, past decisions or perhaps even mistakes too.

In the construction of the Financial Capability Index, it was pivotal to differentiate financial literacy and financial education of an individual as the latter is included in CFCS 2014 as a variable (of pursuing a financial, economic or general accounting course program in the last five years) that is considered to a professional or academic paradigm. Whereas, the individual's own understanding of functions of money, credit, risk and future expectations through everyday financial transactions pertain to good practices in varying age, lifestyles and income groups. 


\section{icalibme}

$3^{\text {rd }}$ International Conference on Advanced Research in

Therefore, the latter is considered in the construction of the Index whereas the former is played as a dummy variable and interactions with other independent variables.

Table 1 shows the number of people that have taken a course or program of the economy or financial matters in the past five years or not. Apparently, most people have not taken the course, and compared to the young people aged 18 to 24, elders take fewer courses or programs.

\begin{tabular}{|c|c|c|c|c|}
\hline Ever taken course & Age group & Female & Male & Grand Total \\
\hline \multirow{9}{*}{ Yes } & $18-24$ & 45 & 46 & 91 \\
\hline & 25-34 & 59 & 72 & 131 \\
\hline & $35-44$ & 55 & 45 & 100 \\
\hline & $45-54$ & 43 & 43 & 86 \\
\hline & 55-59 & 24 & 14 & 38 \\
\hline & $60-64$ & 11 & 14 & 25 \\
\hline & $65-69$ & 12 & 14 & 26 \\
\hline & 70 and over & 14 & 14 & 28 \\
\hline & Grand Total & 263 & 262 & 525 \\
\hline \multirow{7}{*}{ No } & $18-24$ & 143 & 124 & 267 \\
\hline & 25-34 & 389 & 318 & 707 \\
\hline & $35-44$ & 455 & 439 & 894 \\
\hline & $45-54$ & 591 & 551 & 1142 \\
\hline & 55-59 & 338 & 284 & 622 \\
\hline & $60-64$ & 339 & 304 & 643 \\
\hline & $65-69$ & 335 & 278 & 613 \\
\hline
\end{tabular}




\begin{tabular}{|c|c|c|c|}
\hline 70 and over & 756 & 513 & 1269 \\
\hline Grand Total & 3346 & 2811 & 6157 \\
\hline Invalid & 1 & 2 & 3 \\
\hline Grand Total & 3610 & 3075 & 6685 \\
\hline
\end{tabular}

Source: Author's compilation

\subsubsection{Managing Money}

Money management contains three aspects. Firstly, it evaluates whether a person has a good budgeting ability; for example, it requires people to be aware of periodical expenses and to make sure the daily consumption spending always meet their expectations. A person with excellent financial budgeting ability can usually work out their budget well, including some lumpy expenditure, can keep records that have a good credit history, and can often check their statements and balances. Secondly, it focuses on people's resistance to advertising, that is, whether people can restrain their desire to consume when they see advertising promotions through any channel. Thirdly, people's perception of credit history is also crucial. On the one hand, people are supposed to focus on accumulating credit from day-to-day consumption; on the other hand, people should be aware of the importance of credit records.

Noticeably, managing money is the most significant part of evaluating an individual's financial capability compare to the other three parts because if a person is not able to manage money well in daily life, then the financial capacity of these people must be inferior to others.

The relationship between an individual's factors that might affect people's FCI and the budgeting ability in money management is coherent to how individuals are able to live within their means (See Appendix Table2). We consider three subcategories that are contained in the budgeting ability of whether people work out budgets, keep records, and how often do they check their statements. As it showed in the chart, most people cannot work out budgets especially for the elders who are over 70, accounting for $88.3 \%$, low income (less than $\$ 24,999$ ) people, accounting for over $80 \%$, and low education (high school or less) group, which accounts for $82.6 \%$. On average, over $80 \%$ of people could keep records except for the low income (less than $\$ 24,999$ ) people and low education (high school or less) people. As for checking statement, it is better for citizens who can check their bank statement within a month because those people have understood the importance of credit and they probably could keep a good credit record. According to the table 2 (see Appendix), we can find that more than 95\% of people can check their statements within a month. Among them, the younger they are, the more often they check their bills. For example, more than $50 \%$ of people aged 18 to 59 check their tabs once a week; $48.6 \%$ of the elderly check their bills monthly. Over $70 \%$ of financial literate people review their statements frequently (within weekly) than others who are illiterate, and that over $40 \%$ of them check bills over a month. In other words, if a person has an excellent financial capability, 
she or he is expected to work out budgets well, keep records, and check the statements frequently.

In addition, as we mentioned that it is very important to keep a good credit, which means people should have to maintain good living consumption habits. The chart 2 shows the frequency of staying within budget. Obviously, if respondents choose "always" and "frequency", which means their living habits are very good, that is, their ability to manage money is higher, which can improve their FCI. Furthermore, among the people who choose always, the proportion of middle-aged and elderly is the highest (over 60 years old accounted for $16 \%$ ), indicating that they usually have a stronger ability to plan and manage money, so their FCI is also higher.

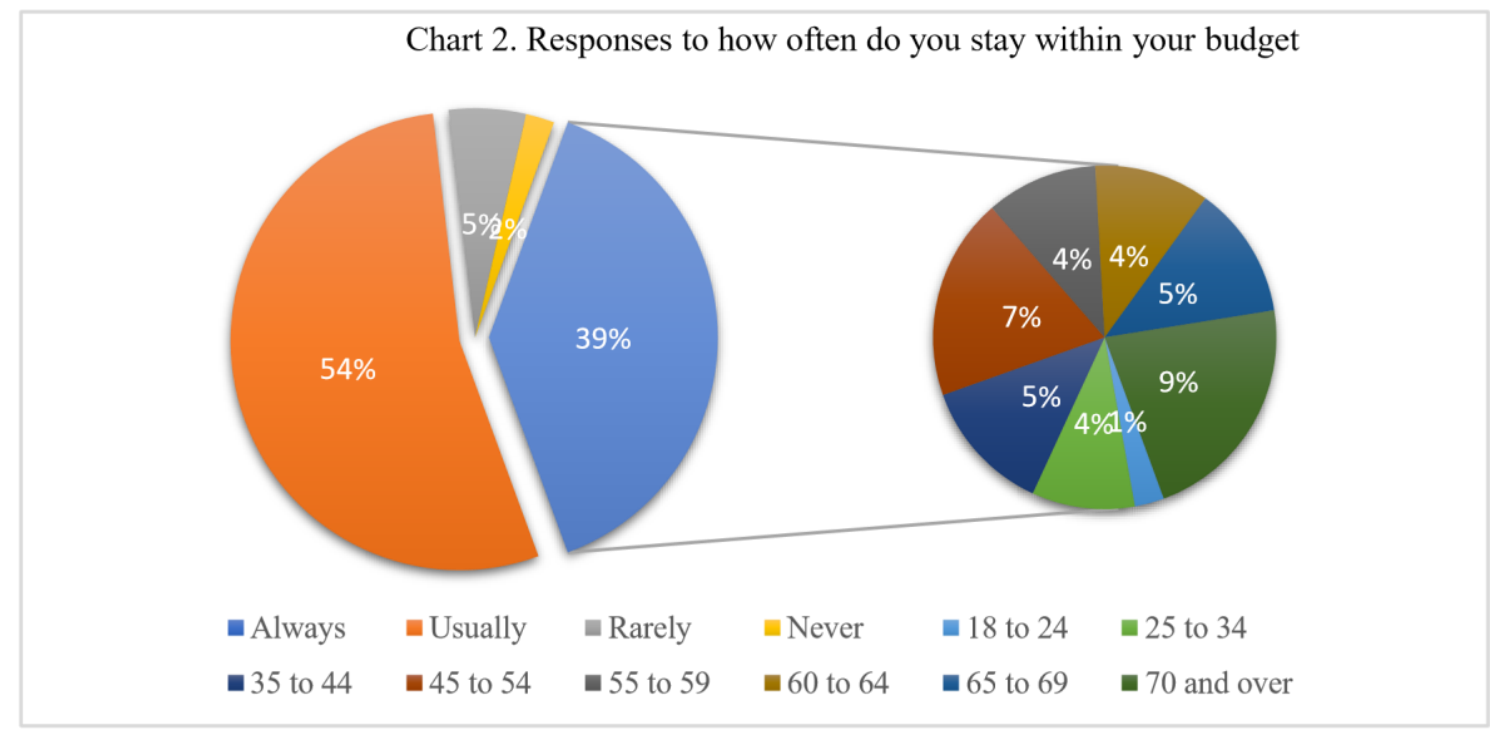

Source: Author's compilation

\subsubsection{Planning Ahead}

Planning ahead should be considered in terms of four sub-categories, that include savings, long-term planning, unexpected expenditure, and debts. Firstly, savings are critical, and most people save for significant expenses such as buying a house or car or for unpredictable emergencies. At the same time, savings and income are also related. For low-income people, it is difficult for them to have extra money as savings, while for high-income people, savings have become one of their regular financial activities. Therefore, there is a strong relationship between saving and planning ahead. Secondly, long-term planning is one of the crucial aspects that should be considered. People of any age should have corresponding plans and arrangements, such as buying a car, child education expenses, helping children buy a house, etc. It is worth noting that pensions should be valued, and people can choose to participate in government pension plans or commercial pension insurance. Thirdly, unexpected expenditure is also one of the essential factors to test whether people can plan ahead. It can detect if people have enough funds to deal with a sudden bill. At the same time, by setting the number of bills differently, it 
can analyze the level of people's ability to cope. Finally, the debt situation needs to be noticed. People with higher debt are generally considered to have relatively lower score in the pillar of planning-ahead. As an example from the dataset the source of short and long term debts of the population is provided below in Chart 3 and observe that mortgage payments play a major contribution towards long term debts while outstanding credit card balances (approximately 2000 individuals) lower the FCI score.

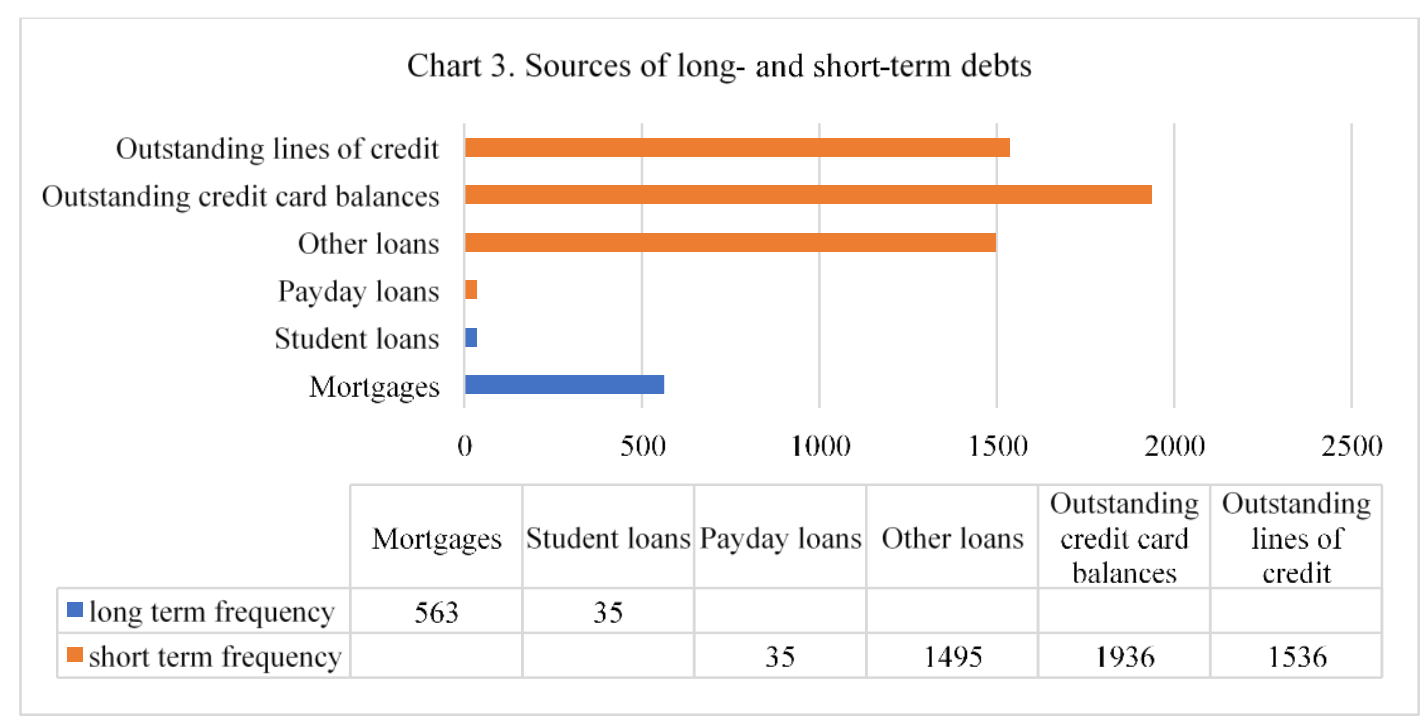

Source: Author's compilation

Moreover, the sources through which one would expect to address any unexpected expenses that can be of small and big amount of transactions is also important to note in the pillar of planning ahead. This methodology of analyzing spending patterns is prevalent in both Basic Skills Financial Capability Framework (Basic Skills Agency, 2004) and even studies in Croatia and Canada (Bahovec et al. 2017). The chart below explains the number of respondents tending towards the different sources of money providers in case of unexpected expenditure were to occur. As one can see, using a credit card or one's savings are the most popular when addressing small unexpected expenditure whereas borrowing from a financial institution or selling a financial asset are more popular in case of bigger unexpected expenditures. This pattern is relevant towards financial products such as insurance. As a financial instrument, it is an integral component juxtaposed with several other sub-parameters of an individual's financial capability when he or she is planning ahead of uncertain expenditures. 


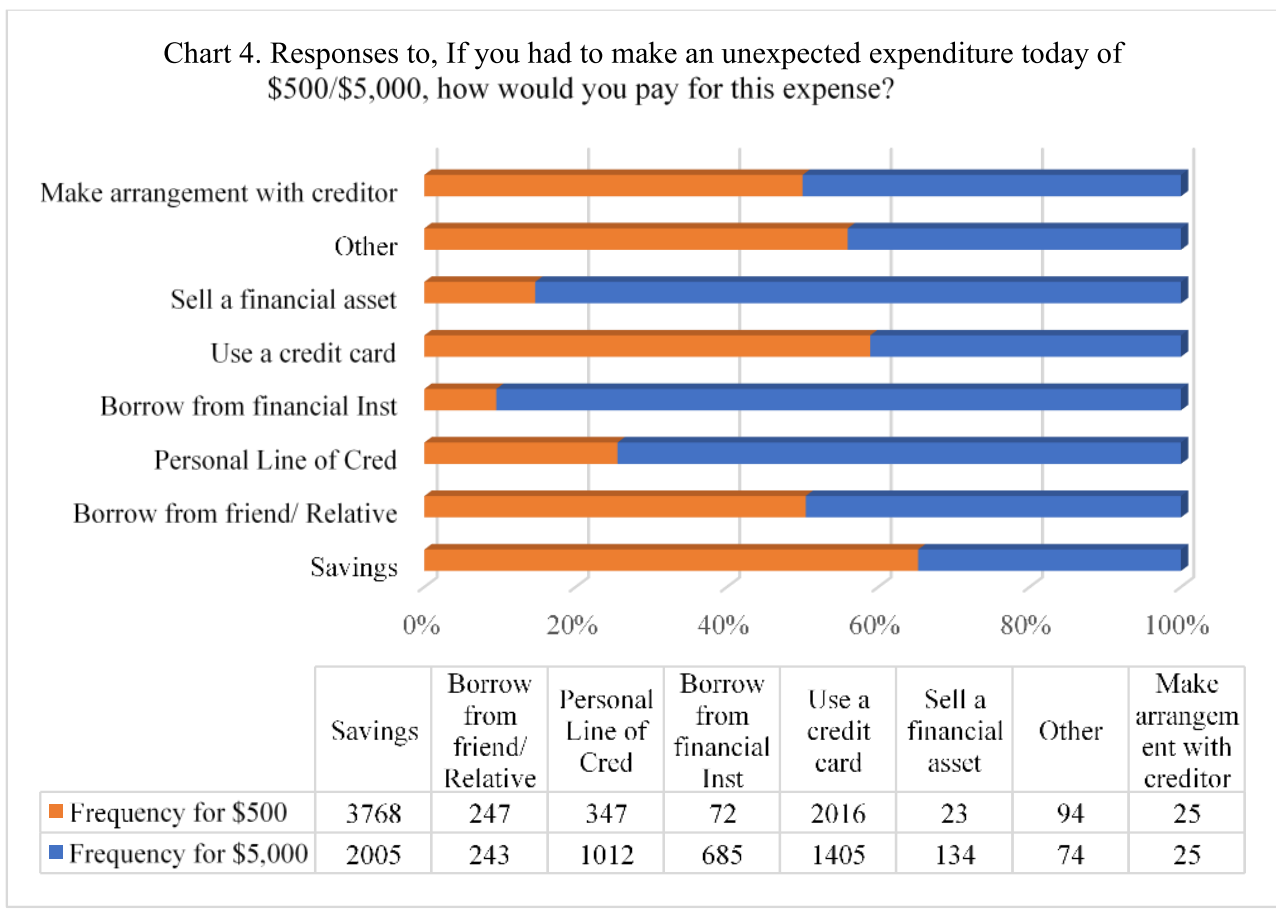

Source: Author's compilation

Table 3 (see Appendix Table 3) shows whether people have any financial retirement plans, which is unequivocally correlated to the pillar planning ahead. Obviously, with more retirement financial plans or their sources, the FCI should be higher. According to the chart, young people and middle-aged people have more retirement plan than older people, especially those more aged than 70 years of age who basically do not have any plan, and more than $45 \%$ of 25 to 64 years old people have government pensions, corporate pensions, and personal pension gold. It is worth noting that people aged 35 to 54 have more options besides the pensions mentioned above, for example, they can sell financial and non-financial assets and run their businesses to support their elderly life. People who are financially literate have more kinds of financial retirement plans than others, and the same trends are presented in the income level and education level. With the improvement in income level and education level, people's financial retirement plans will be significantly improved. Nearly $50 \%$ of people with a personal income of more than $\$ 40,000$ and more than $50 \%$ of university graduates have government pensions, corporate pensions, and personal pensions. People with higher debts and liabilities have more plans, interestingly, $22 \%$ of them with debts greater than $\$ 250,000$ will choose to sell financial and non-financial assets to support their old age. In general, middle-aged, high-income and highly educated people (above high school level) with high debt and reliability, have more retirement financial plans, and at the same time, more people have plans, most of which have a pension, personal pension and workplace pension. 


\subsubsection{Making Choices}

Making choice is mainly to investigate three aspects. One is whether people can shop around while paying attention to the product-related policy terms. For example, some small prints which are important on the packaging are usually tricky for merchants. Second, people's awareness of risk, that is, different people's tolerance and understanding of risk are different. The third is people's ability to reserve financial knowledge, and to test an individual's level through general financial questions.

Table 4 (see Appendix Table 4) is given a specific scenario, that if the respondent has a university tuition fee, then where should the money be placed is the safest. First, the return of funds is positively related to the risk; that is, high returns are usually accompanied by high risks. Of the five options given, a bank saving account and lock in safe at home are relatively safe, while the stock market, corporate bonds, and mutual funds are relatively high risk. Then, considering that university tuition is not an idle fund, but a necessary education fund to be paid in the future, the best way to deal with this money should be to place it in a low-risk place, such as a bank deposit or home, rather than take it to make an investment. Secondly, overall, more than $70 \%$ of people choose to put the university money in banks, followed by funds, and less than $4 \%$ of people choose to put them in the stock market. If we set the bank is regarded as the safest place, then the people of financial literacy will be more inclined to low-risk operations that they probably choose to put the money to the bank account. In addition, the higher the level of income and education, the more people choose to deposit in the bank also higher.

An individual's self-assessment of making ends meet can be a good judge of whether shopping behavior is valuable. From chart 5, in general, most people's choices can meet their expectations. Among them, the higher the education level, the more likely people are to achieve goals. There are only 8 graduate students (1.8\% of their total number) and 19 undergraduate students $(1.4 \%$ of their total number) chose not very good, and 71 people with a high school degree or below $(3.2 \%$ of their total number) chose not very good, which shows that people's education level can affect their behavior and expectations.

Chart 5. Responses to How would you rate yourself on each of the following areas of financial management: making ends meet

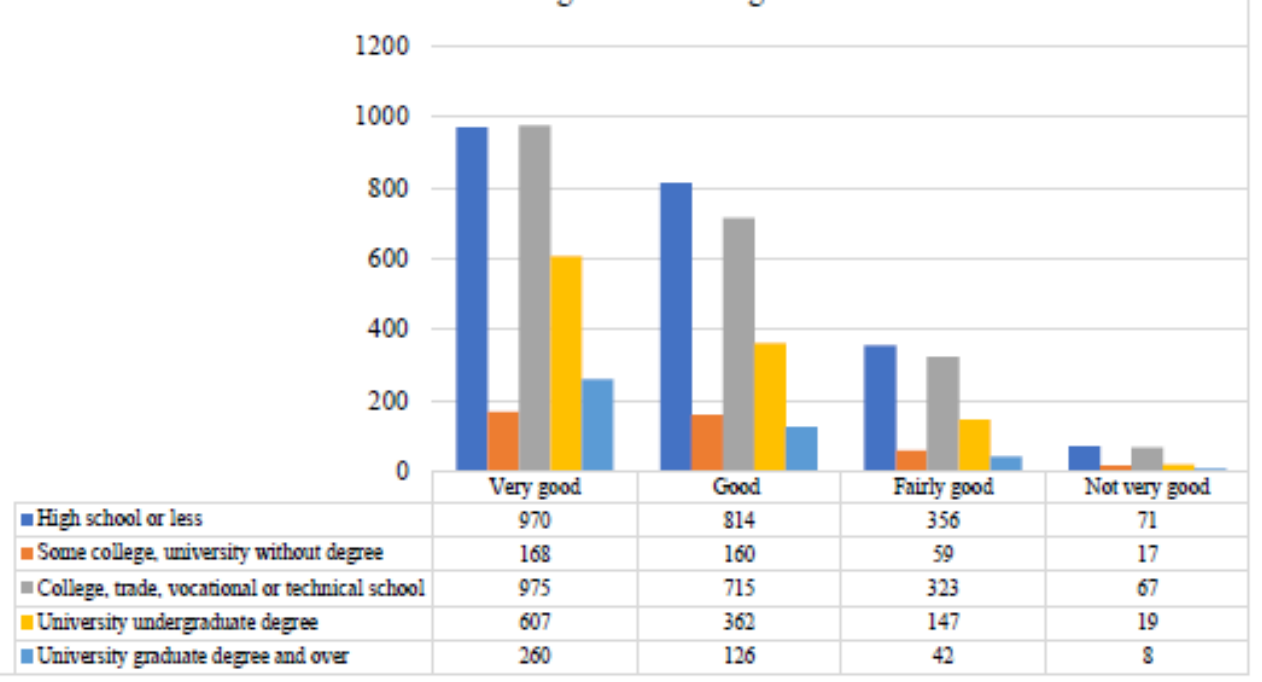


Source: Author's compilation

\subsubsection{Getting Help}

Getting help focuses on two parts. First, people's attitude towards collecting background information in daily life, and through which medium or channel to obtain information, such as television, Internet, and newspapers. Second, when a specific problem is encountered, what is the response of people, for example, people could choose to acquire the information to solve the problem or ask for help from a third party. If you choose the former, the credibility of the information is worth to be noted, that if the latter is selected, then the professionalism and authority of the third party should also be considered.

It is fortunate to see that if people could ask for help when they make financial choices or meet financial troubles, but it is considerable that the professionalism of their access to information. Chart 6 shows that the financial and non-financial channels that they might use. Intuitively, the number of people choosing financial and non-financial channels is similar. Among them, 1855 people choose to listen to commercial programs through radio or tv, and 1212 people decide to consult financial experts. Good choice. While 1440 people choose to browse newspapers, and 2190 people decide to search online. It is undeniable that these methods may be helpful, but the mixed information of these channels may interfere with people making the right choices.

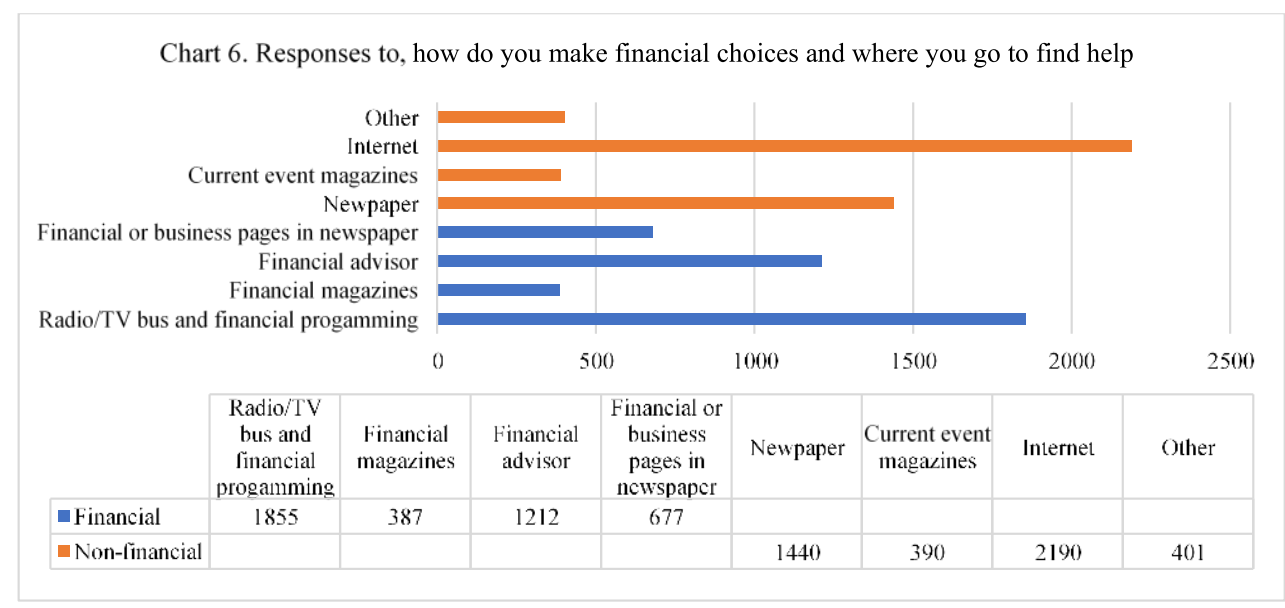

Source: Author's compilation

Table 5 (see Appendix Table 5) asks whether people have paid or sought advice on financial products in the past year. First, unfortunately, more than $50 \%$ of respondents in each group chose 'No', and second, in terms of specific types of financial products, nearly $40 \%$ of people aged 25 to 69 are more inclined to retirement planning and financial planning. Financially literate people also have a higher percentage of seeking advice on financial products than those who are financially illiterate. Higher-income and higher educated people will also be more inclined to consult financial products. Among them, more than $30 \%$ of high-income people (\$ 63,000 and over) and high-education people (university graduate degree and over) and more than $40 \%$ people who have over $\$ 250,000$ RRSPs will choose financially planning and 
retirement planning. The difference of gender and debts and abilities do not have a significant impact on opinions about whether people choose to consult financial products.

\subsection{Data Information}

All the data is sourced from the Canadian financial capability survey (2014) that contains 6685 observations from all provinces. To construct the financial capability index (FCI) which ranges from 0 to 100 , we need to classify the questions from the survey and weigh each category based on its importance. The table 6 shows the specific category (pillars) and subcategory and the result of the preliminary data findings.

\begin{tabular}{|c|c|c|c|c|c|c|}
\hline \multicolumn{2}{|c|}{ Variable } & \multicolumn{2}{|c|}{ We ght } & \multicolumn{2}{|c|}{$M$ san } & SD \\
\hline \multirow{3}{*}{$\begin{array}{c}\text { Money } \\
\text { Management }\end{array}$} & Budget & 25 & \multirow{3}{*}{40} & 17.85 & \multirow{3}{*}{25.55} & \multirow{3}{*}{6.63} \\
\hline & Pressure & 5 & & 3.84 & & \\
\hline & Borrowing and credit & 10 & & 3.85 & & \\
\hline \multirow{4}{*}{ Making Choice } & Shopping around & 6 & \multirow{4}{*}{23} & 3.77 & \multirow{4}{*}{15.97} & \multirow{4}{*}{5.24} \\
\hline & Risk & 2 & & 1.50 & & \\
\hline & Financial literacy & 8 & & 5.39 & & \\
\hline & Self-rating & 7 & & 5.31 & & \\
\hline \multirow{4}{*}{ Planning Ahead } & Saving & 4 & \multirow{4}{*}{26} & 1.26 & \multirow{4}{*}{14.30} & \multirow{4}{*}{4.84} \\
\hline & Long term plan & 7 & & 2.31 & & \\
\hline & Unexpected plan & 8 & & 5.25 & & \\
\hline & debts & 7 & & 5.47 & & \\
\hline \multirow{2}{*}{ Getting Help } & Background information & 6 & \multirow{2}{*}{11} & 0.95 & \multirow{2}{*}{1.91} & \multirow{2}{*}{2.26} \\
\hline & Specific issues & 5 & & 0.96 & & \\
\hline
\end{tabular}

Source: Author's compilation (in \%)

\section{Model and Results}

\subsection{Variable Choices}

In order to analyze the factors that affect people's financial capability, we selected relevant influence variables from the survey. Table 7 shows the variables which will be used in this paper in detail. We expect the factors which probably affect FCI including age, financial literacy, income, education, assets, debts and liability, and other factors such as household income as well as introducing dummy variables. Economic intuition suggests that as age, education, personal income increases the financial capability of the individual. Moreover, as acquisition of tangible assets and investing into Registered 
Retirement Savings Plans (RRSPS) would also ascertain positive relationship with the Financial Capability Score of the individual. In accordance of the same intuition it would be considered that estimated value of debts and liabilities would inversely relate with financial capability score, however it is not unexpected to even have a positive relationship. This is because debt behavior as an explanatory variable does not necessarily have an exact negative relationship with the financial capability of the individual. Debts are necessary to acquire commodities and services in the economy that cannot be bought with mere cash or savings of an individual in his or her lifetime. As mentioned earlier, mortgages play as a major contributor in long term debts and that is essentially because one cannot make a huge expense on a house without accumulation of capital to invest into an asset such as a house. Therefore, respondents can exhibit different behaviors to debt with difference in demographics, financial literacy, gender and even income levels (Bahovec et al. 2015).

\begin{tabular}{|c|c|c|}
\hline Variable Name & Variable in this paper & Measurement in Raw Data \\
\hline Age of respondent & Age & Contains 8 categories or levels from $18-24$ to 70 and over \\
\hline $\begin{array}{l}\text { Age of respondent } \\
\text { Squared }\end{array}$ & AgeSq & $\begin{array}{c}\text { Contains } 8 \text { Categories or levels squared of the age of the } \\
\text { respondent }\end{array}$ \\
\hline Gender & SEX & Gender of the respondent \\
\hline $\begin{array}{l}\text { Highest level of school } \\
\text { attained }\end{array}$ & Edu & $\begin{array}{c}\text { Contains } 5 \text { categories or levels from high school or less to } \\
\text { university graduate degree }\end{array}$ \\
\hline Income-personal level & PINQUIN & $\begin{array}{c}\text { Personal income before taxes and deductions in } 2013 \text {, } \\
\text { contains } 5 \text { categories from less than } \$ 13,001 \text { to } \$ 63,001 \text { and } \\
\text { over }\end{array}$ \\
\hline Financial Education & $\mathrm{FE}$ & $\begin{array}{l}\text { Have ever taken course or program relate to economy or } \\
\text { financial matters }\end{array}$ \\
\hline Estimated value of RRSPs & RP & $\begin{array}{l}\text { Contains } 8 \text { categories of current value of tangibles assets } \\
\text { from less than } 25,000 \text { to } 250,000 \text { and more }\end{array}$ \\
\hline $\begin{array}{l}\text { Estimated value of } \\
\text { Tangible Assets }\end{array}$ & AS & $\begin{array}{l}\text { Contains } 6 \text { categories of current value of tangibles assets } \\
\text { from less than } 100,000 \text { to } 500,000 \text { and more }\end{array}$ \\
\hline $\begin{array}{l}\text { Estimated value of debts } \\
\text { and liability }\end{array}$ & DL & $\begin{array}{l}\text { Contains } 6 \text { categories or levels from less than } \$ 50,000 \text { to } \\
\qquad \$ 250,000 \text { or more }\end{array}$ \\
\hline Others & $\mathrm{Xi}$ & $\begin{array}{l}\text { Including household size, household income and introducing } \\
\text { dummy variables }\end{array}$ \\
\hline
\end{tabular}

Source: Author's compilation

\subsection{Ordinary Least Squares Approach}

By dropping the individuals who did not provide any data to the estimated value of debts and liabilities, the data set with 3505 valid observations and by application of the OLS estimation technique we obtained the following results:

$$
F C I(Y)=\beta_{1}+\beta_{2} A g e+\beta_{3} A g e^{2}+\beta_{4} \operatorname{Sex}+\beta_{5} F L+\beta_{6} I n c+\beta_{7} E d u+\beta_{8} A S+\beta{ }_{9} \mathrm{DL}+\beta_{10} X_{i}+\varepsilon
$$




\section{icalinme}

$3^{\text {rd }}$ International Conference on Advanced Research in

STOCKHOLM, SWEDEN BUSINESS, MANAGEMENT \& ECONOMICS

Table 8. Regression results (I)

Dependent Variable: TotalFCI (Total score in accordance to Financial Capability Index)

\begin{tabular}{|c|c|c|c|c|}
\hline \multirow[t]{2}{*}{ Variables } & \multicolumn{4}{|c|}{ Coefficient Estimates and (Standard Errors) } \\
\hline & Specification A & Specification B & Specification C & Specification D \\
\hline \multirow[t]{2}{*}{$\mathrm{C}$} & $54.77478^{* * *}$ & $54.60365^{* * *}$ & $65.83304 * * *$ & $3.956748^{* * *}$ \\
\hline & $(1.600317)$ & $(1.87097)$ & (1.682449) & (1.61283) \\
\hline \multirow[t]{2}{*}{ SEX } & $1.010683^{* * *}$ & 1.125454 & $-1.399076^{* * *}$ & $.8277146 * *$ \\
\hline & $(.3446337)$ & $(.7355668)$ & $(.3691794)$ & $(.346788)$ \\
\hline \multirow[t]{2}{*}{ Age } & $-1.252945 * *$ & $-1.253821^{* * *}$ & $2.566023^{* * *}$ & $-1.207929 * * *$ \\
\hline & (.4188569) & $(.4189443)$ & $(.4478984)$ & $(.4180715)$ \\
\hline \multirow[t]{2}{*}{ AgeSq } & $.0938687^{* *}$ & $.0938752^{* *}$ & $-.2778452^{* * *}$ & $.0971414^{* *}$ \\
\hline & $(.0443654)$ & $(.0443716)$ & $(.0477274)$ & $(.0442741)$ \\
\hline \multirow[t]{2}{*}{ Edu } & $.7991039 * * *$ & $.858823^{* *}$ & $1.673156^{* * *}$ & $.7744166 * * *$ \\
\hline & (.1210434) & $(.3591357)$ & (.1313069) & $(.1209262)$ \\
\hline \multirow[t]{2}{*}{ PINQUIN } & $2.151003^{* * *}$ & $2.152278^{* * *}$ & & $1.740905^{* * *}$ \\
\hline & (.1492692) & (.1494643) & & (.1797663) \\
\hline \multirow[t]{2}{*}{$\mathrm{FE}$} & $-3.95821^{* * *}$ & $-3.95895 * * *$ & $-4.275357^{* * *}$ & $-3.956415^{* * *}$ \\
\hline & $(.5501691)$ & $(.5502613)$ & $(.6174435)$ & $(.5489458)$ \\
\hline \multirow[t]{2}{*}{ RP } & $1.062904^{* * *}$ & $1.062636^{* * *}$ & & $1.019776 * * *$ \\
\hline & $(.0767627)$ & $(.0767884)$ & & $(.0773202)$ \\
\hline \multirow[t]{2}{*}{ AS } & $1.12617^{* * *}$ & $1.126222^{* * *}$ & & $1.043287^{* * *}$ \\
\hline & (.100275) & $(.1002893)$ & & (.1020996) \\
\hline \multirow[t]{2}{*}{ SEX*Edu } & & -.0404245 & & \\
\hline & & $(.2288747)$ & & \\
\hline \multirow[t]{2}{*}{$\mathrm{DL}$} & 1363729 & 136989 & $-.9213097^{* * *}$ & $.1726879 *$ \\
\hline & (.1046474) & (.10472) & $(.1052332)$ & (.1047945) \\
\hline \multirow[t]{2}{*}{ HINCQUIN } & & & & $.7596727^{* * *}$ \\
\hline & & & & (.1864754) \\
\hline SSE & 137275.992 & 137278.93 & 48433.345 & 138831.48 \\
\hline
\end{tabular}




\begin{tabular}{|c|c|c|c|c|}
\hline$R 2$ & 0.2944 & 0.2944 & 0.1039 & 0.2977 \\
\hline \multicolumn{5}{|c|}{ Source: Author's compilation } \\
\hline \multicolumn{5}{|c|}{ *** Significant at the 1 percent level } \\
\hline \multicolumn{5}{|c|}{ ** Significant at the 5 percent level } \\
\hline
\end{tabular}

According to our estimation results of specification (A), we find that gender, education, personal income before taxes in 2013 have expected positive signs. Similarly, tangible assets (AS) and estimated value of RRSPS (RP) are significant at one percent level and positive in predicting the dependent variable Financial Capability Index. However, as anticipated we observe a positive sign in case of estimated value of debts and liabilities (DL), although it is found to be insignificant. The $\mathrm{R}$ squared value suggests that about thirty percent of the variation in the FCI is explained by the independent variables. In contrast of specification (A), in specification (B) we see that gender becomes insignificant even at ten percent, as the interaction with gender and education as well is insignificant. It is important to note in both specification (A) and (B) that on average, ceteris paribus, an increase in the level or category of personal income increases the financial capability score by approximately two points. In specification (C) there is stark difference in the coefficient estimates of value of debts and liabilities (DL) than its other counter parts estimated in other specifications. It not only is negative, but it also shows significance at one percent level. To observe and analyze whether certain variables should be included in the model, an F test was implemented with specification (C) as the restricted model and specification (A) as the unrestricted model. With absence of tangible assets (AS), personal income (Inc) and value of RRSPs (RP) we observe that we reject the null hypothesis: that at least one of the estimated coefficient values of the previously stated variables are equal to zero at one percent level. This is an exceptional result as it suggests that having registered retirement saving plan and acquisition of assets such as houses, automobiles, home furnishings, business assets, jewelry, inheritance are significant variables in predicting the financial capability of the individual.

In specifications (A), (B) and (D), the age category is negative, and the squared value of the age group is positive that points out that for the young (18-24, 25-34 age categories) and middle age (35-44, 45-54 age categories) have high financial capabilities, while older generations have lower financial capabilities. Moreover, respondents under the age of 70 attain sufficient financial capability score because of the value of their tangible assets and estimated value of RRSPs. Specification (C) however, shows the concave function suggesting that the middle age categories have the highest financial capability and successively reduces as the age increases. This goes along with the literature review mentioned earlier. Finally, the most crucial aspect of financial capability that is the individual's financial education in all four specifications shows a negative relation with the dependent variable. On average, ceteris paribus, if an individual has attained or studied a course in financial matters or in general an economics course reduces the financial capability of that individual by approximately four points. In all four specifications, the coefficient of the dummy variable; attainment of financial education (FE) is significant at one percent level. This contradicts much of the literature that suggests that financial literacy is 
monumental in attaining a satisfactory financial capability score. Although, there were only 525 respondents that had pursued financial education out of which a majority were in the age category of the younger and middle-aged population as the table suggests below:

Table 9. Financial Education: In the past five years, have you taken a course or program of study to increase your knowledge and understanding of the economy or financial matters

\begin{tabular}{|c|c|c|c|c|c|c|c|}
\hline Financial Edu & Column Labels & & & & & & \\
\hline & Yes & & $\begin{array}{l}\text { Yes } \\
\text { Total }\end{array}$ & No & & $\begin{array}{l}\text { No } \\
\text { Total }\end{array}$ & $\begin{array}{l}\text { Grand } \\
\text { Total }\end{array}$ \\
\hline Row Labels & Female & Male & & Female & Male & & \\
\hline 18 to 24 & 21 & 17 & 38 & 70 & 61 & 131 & 170 \\
\hline 25 to 34 & 47 & 55 & 102 & 275 & 239 & 514 & 616 \\
\hline 35 to 44 & 41 & 33 & 74 & 320 & 335 & 655 & 729 \\
\hline 45 to 54 & 28 & 30 & 58 & 372 & 364 & 736 & 794 \\
\hline 55 to 59 & 13 & 9 & 22 & 163 & 165 & 328 & 350 \\
\hline 60 to 64 & 6 & 9 & 15 & 154 & 184 & 338 & 353 \\
\hline 65 to 69 & 2 & 7 & 9 & 112 & 104 & 216 & 225 \\
\hline 70 and over & 2 & 9 & 11 & 124 & 133 & 257 & 268 \\
\hline Grand Total & 160 & 169 & 329 & 1590 & 1585 & 3175 & 3505 \\
\hline
\end{tabular}

Source: Author's compilation

In order to have a better understanding while clearly making a distinction between financial education and financial literacy, we used the OLS estimation technique by regressing the individual's score in the pillar of Making choices with the independent dummy variables of financial literacy score (subcategory of the pillar) attained by respondents. By using the tabulate command on Stata and converting the score of financial literacy into an ordinal categorical variable we define three levels or orders: financial literate (FL11), partially financial literate (FL13) and financially illiterate (FL12). The following secondary regression model is given below with FL13 as base value:

Making Choice Score $=\beta_{1}+\beta_{2} S E X+\beta_{3} F L 11+\beta_{4} F L 12+\varepsilon$

The table 10. below exclaims the percentage of respondents in accordance of their financial literacy (from the survey), gender and income levels 


\section{icalinme}

$3^{\text {rd }}$ International Conference on Advanced Research in

STOCKHOLM, SWEDEN BUSINESS, MANAGEMENT \& ECONOMICS

\begin{tabular}{|c|c|c|c|c|}
\hline \multicolumn{5}{|c|}{ Financial Literacy Summary as per Income Levels } \\
\hline Row Labels & $\begin{array}{l}\text { financially } \\
\text { literate }\end{array}$ & $\begin{array}{l}\text { financially } \\
\text { illiterate }\end{array}$ & $\begin{array}{l}\text { partially financially } \\
\text { literate }\end{array}$ & $\begin{array}{l}\text { Grand } \\
\text { Total }\end{array}$ \\
\hline Income level Less than $\$ 13,001$ & $5.93 \%$ & $1.17 \%$ & $3.85 \%$ & $10.96 \%$ \\
\hline Female & $4.56 \%$ & $0.91 \%$ & $2.60 \%$ & $8.07 \%$ \\
\hline Male & $1.37 \%$ & $0.26 \%$ & $1.26 \%$ & $2.88 \%$ \\
\hline Income level \$13,001 - \$24,999 & $8.42 \%$ & $1.40 \%$ & $4.62 \%$ & $14.44 \%$ \\
\hline Female & $5.45 \%$ & $0.91 \%$ & $2.91 \%$ & $9.27 \%$ \\
\hline Male & $2.97 \%$ & $0.49 \%$ & $1.71 \%$ & $5.16 \%$ \\
\hline Income level $\$ 25,000$ - $\$ 39,999$ & $14.95 \%$ & $1.28 \%$ & $6.56 \%$ & $22.80 \%$ \\
\hline Female & $8.64 \%$ & $0.68 \%$ & $3.45 \%$ & $12.78 \%$ \\
\hline Male & $6.31 \%$ & $0.60 \%$ & $3.11 \%$ & $10.01 \%$ \\
\hline Income level \$40,000 - \$62,999 & $18.06 \%$ & $0.63 \%$ & $5.05 \%$ & $23.74 \%$ \\
\hline Female & $8.30 \%$ & $0.37 \%$ & $2.43 \%$ & $11.10 \%$ \\
\hline Male & $9.76 \%$ & $0.26 \%$ & $2.62 \%$ & $12.64 \%$ \\
\hline Income level $\$ 63,000$ and over & $23.28 \%$ & $0.94 \%$ & $3.85 \%$ & $28.07 \%$ \\
\hline Female & $7.08 \%$ & $0.37 \%$ & $1.28 \%$ & $8.73 \%$ \\
\hline Male & $16.21 \%$ & $0.57 \%$ & $2.57 \%$ & $19.34 \%$ \\
\hline Grand Total & $70.64 \%$ & $5.42 \%$ & $23.94 \%$ & $100.00 \%$ \\
\hline
\end{tabular}

Source: Author's compilation

In percentage $(\%)$

According to the table above a mere five percent of the population is financially illiterate while a good chunk of the population is financially literate across the increasing levels of income. The secondary regression model thereby gives us the following results:

Table.11 Regression results (II)

Dependent Variable: Score on Making Choice (23\% of Financial Capability Index)

\begin{tabular}{|c|c|c|c|c|}
\hline Variables & Coefficient Estimates & Standard Error & t-statistic & p-value \\
\hline C & 17.24648 & .1644952 & 104.84 & 0.000 \\
\hline SEX & -.3316726 & .09309 & -3.56 & 0.000 \\
\hline FL11 & 2.041848 & .1052158 & 19.41 & 0.000 \\
\hline
\end{tabular}




\begin{tabular}{|l|l|l|l|l|}
\hline FL12 & -3.888533 & .1405135 & -27.67 & 0.000 \\
\hline
\end{tabular}

Source: Author's compilation

From the above table we can see that financial literacy level FL13 (partially financially literate) is taken as the base value with FL11 and FL12 acting significant ordinal categorical variables in estimating the score of making choices pillar. The pvalue statistic suggests that all estimates are significant at one percent level. In summary an individuals' ability in making financially sound decisions is highly affected by the financial literacy of the individual. This culminates the awareness and basic technical know-how of risk, best products, inflation and financial products that play an eminent role in ascertaining the financial capability of an individual. On average, ceteris paribus, a financially illiterate individual's score in making choices is approximately thirteen points whereas a financially literate individual's score is approximately twenty which is a significant difference. The variation explained in this secondary model is thirty eight percent that is similar to our previous specifications. Such robustness essentially goes along with previous literature reviewed; however, an essential finding is that financial education not necessarily effects the financial capability of an individual. It is rather the non-academic or self-attained knowledge of financial products, markets or decision-making patterns that accelerates the financial capability of the individual.

\section{Conclusion}

Using the consumer survey, Canadian Financial Capability Survey (CFCS) 2014, implemented by Statistics Canada, we explain the construction of an index that quantifies the best practices of individuals with respect to making informed financial decisions. This is attained by making a scoring mechanism on the responses in the survey of CFCS, 2014. Moreover, we analyze the assessment of the four main domains or pillars for any individual's financial capability: money management, planning ahead, making choices and getting help. Finally, by using the OLS model of estimation we argue that not only does personal income, age, gender and financial assets are significant variables effecting the financial capability, but also tangible assets and registered retirement savings plans are significant variables in the estimation. This pertinently evaluates the typology of consumer financial capability that describes an individuals' strengths and weaknesses.

A secondary finding also conveys that a distinction should be administered between financial education and financial literacy in informed and practiced policy for raising level of financial capability of consumers in the economy. As per the results financial literacy is as a significant parameter that explains the choice patterns of individuals and these informed decisions make up the financial capability of the individual. The study also points out that household income not necessarily explains the variation of the financial capability index and debt behavior is not necessarily in negative relation of the financial capability of an individual. 


\section{Acknowledgment}

This paper is an output of the research that was to be produced in one of the courses at graduate master's program in Economics at the University of Windsor.

\section{References}

[1] Bahovec, V., Barbić, D., and Palić, I. (2017). "The Regression Analysis of Individual Financial Performance: Evidence from Croatia." Business Systems Research, 8(2), 1-13.

[2] Basic Skills Agency (2004), Adult financial capability framework. London: Basic Skills Agency.

[3] Buckland, J. (2010). “Are Low-Income Canadians Financially Literate? Placing Financial Literacy in the Context of Personal and Structural Constraints." Adult Education Quarterly, 60(4), 357-376.

[4] Lusardi, A., and Scheresberg, C.D.B (2016). “Americans' Troubling Financial Capabilities: A Profile of Pre-Retirees." Public Policy \& Aging Report 26(1). 23-29.

[5] Kempson, E., Collard, S., and Moore, N. (2005). Measuring financial capability: an exploratory study. Financial Services Authority.

[6] Mason, C., and Wilson, R. (2000). Conceptualising Financial Literacy. Journal of Consumer Affairs, 39.

[7] Nicolini, G. (2006). Consumer Financial Capability: Empowering European Consumers, Brussels: European Credit Research Institute.

[8] Noctor, M., Stoney, S. and Stradling, R. (1992), Financial Literacy: A Discussion of Concepts and Competences of Financial Literacy and Opportunities for its Introduction into Young People's Learning. Report prepared for the National Westminster Bank, London: National Foundation for Education Research.

[9] Personal Finance Research Centre (2017), Financial capability and retirement. Bristol: Money Advice Service.

[10] Rothwell, D. W., Mohammad, N. K., and Cherney, k. (2016). "Building Financial Knowledge Is Not Enough: Financial Self-Efficacy as a Mediator in the Financial Capability of Low-Income Families." Journal of Community Practice: Financial Capability and Asset Building 24(4), 368-388.

[11] Schellenberg, G., and Ostrovsky, Y. (2010). Retirement-Related Highlights from the 2009 Canadian Financial Capability Survey, Statistics Canada, 26. 


\section{icalityme}

$3^{\text {rd }}$ International Conference on Advanced Research in

\section{Appendix:}

Chart A1: Financial Capability Score distribution across Estimated value of RRSPs.

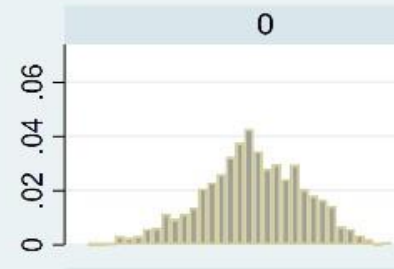

3

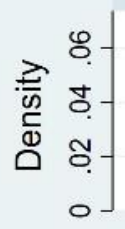

0

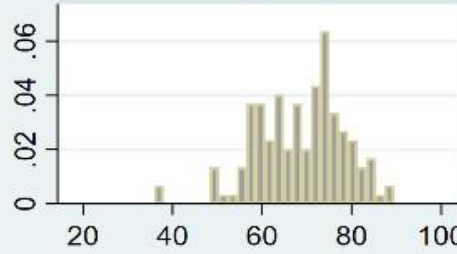

Graphs by AD_G04A
1

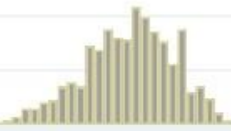

4

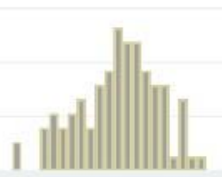

7

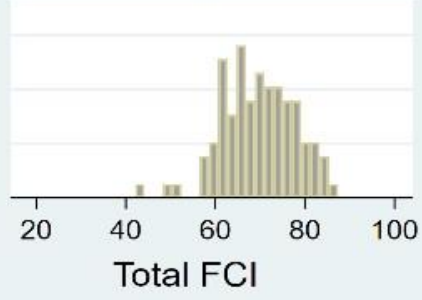

2

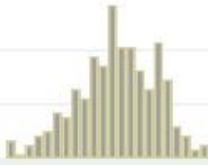

5

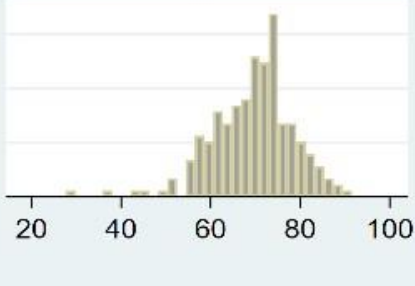

\begin{tabular}{|l|l|l|l|l|l|l|l|l|l|}
\hline Estimated & 0 & 1 & 2 & 3 & 4 & 5 & 7 \\
Category & No & $\begin{array}{l}\text { Less } \\
\text { than } \\
\$ 25,000\end{array}$ & $\begin{array}{l}\$ 25,000 \\
\text { to } \\
\text { under } \\
\$ 50,000\end{array}$ & $\begin{array}{l}\$ 50,000 \\
\text { to under } \\
\$ 75,000\end{array}$ & $\begin{array}{l}\$ 75,000 \\
\text { to under } \\
\$ 100,000\end{array}$ & $\begin{array}{l}\$ 100,000 \\
\text { to under } \\
\$ 125,000\end{array}$ & $\begin{array}{l}\$ 125,000 \\
\text { to under } \\
\$ 200,000\end{array}$ & $\begin{array}{l}\$ 200,000 \\
\text { to under } \\
\$ 250,000\end{array}$ & $\begin{array}{l}\$ 250,000 \\
\text { and over }\end{array}$ \\
\hline Value & RRSP & & &
\end{tabular}

Chart A2: Financial Capability Score distribution across Financially literate, financially illiterate and partially financially literate. 


\section{icalulyme}

$3^{\text {rd }}$ International Conference on Advanced Research in STOCKHOLM, SWEDEN BUSINESS, MANAGEMENT \& ECONOMICS

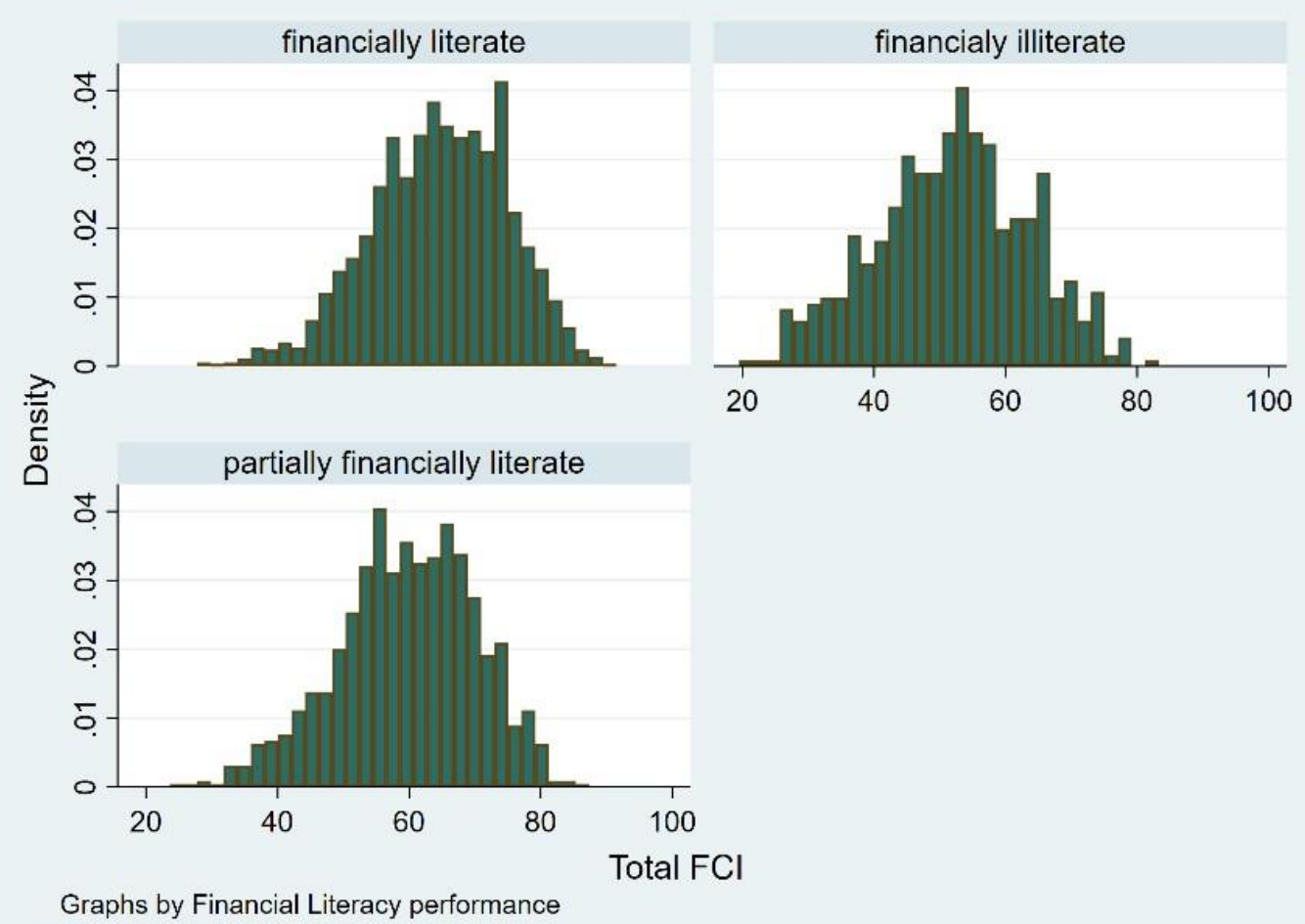

Chart A3: Financial Capability Score distribution across different age categories.

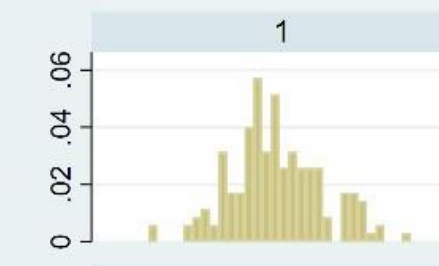

4
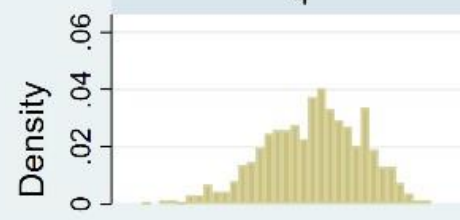

7

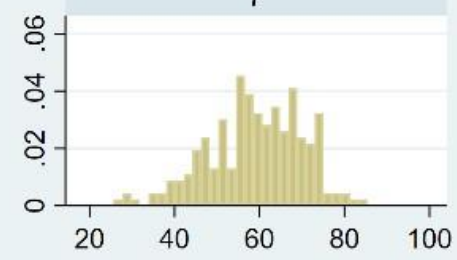

Graphs by G2AGE
2

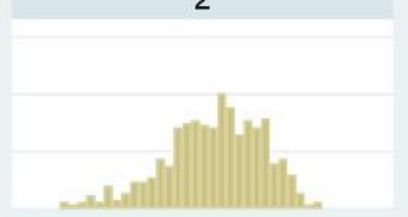

5

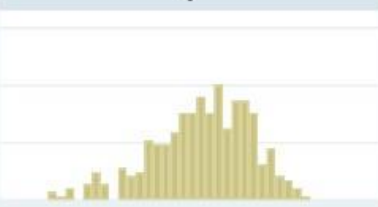

8

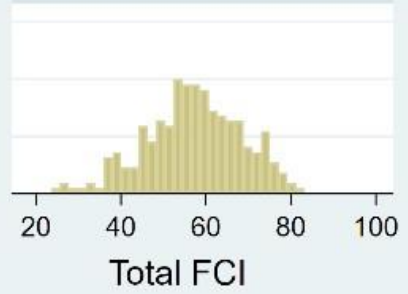

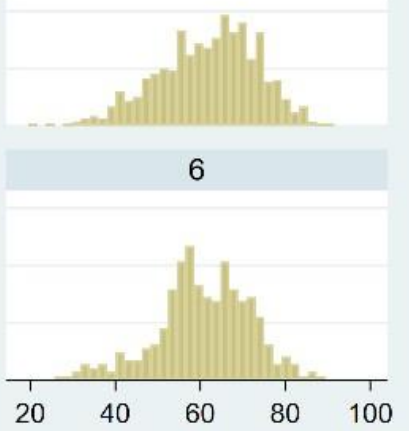

\begin{tabular}{|l|l|l|l|l|l|l|l|l|}
\hline Age Category & 1 & 2 & 3 & 4 & 5 & 6 & 7 & 8 \\
\hline
\end{tabular}




\begin{tabular}{|l|l|l|l|l|l|l|l|l|}
\hline Value & 18 to 24 & 25 to 34 & 35 to 44 & 45 to 54 & 55 to 59 & 60 to 64 & 65 to 69 & $\begin{array}{l}70 \text { and } \\
\text { over }\end{array}$ \\
\hline
\end{tabular}

Table 2. How people deal with their budgeting in money management

\begin{tabular}{|c|c|c|c|c|c|c|c|c|c|c|c|}
\hline \multicolumn{2}{|r|}{ Category } & \multicolumn{2}{|c|}{ Work out budgets } & \multicolumn{2}{|c|}{ Keep records } & \multicolumn{6}{|c|}{ Check statement } \\
\hline & & Yes & No & Yes & No & Daily & Weekly & Half a month & Monthly & Yearly & Never \\
\hline \multirow{8}{*}{ Age } & $\star 18$ to 24 & $33.6 \%$ & $66.4 \%$ & $86.8 \%$ & $13.2 \%$ & $15.5 \%$ & $55.7 \%$ & $19.8 \%$ & $7.9 \%$ & $0.6 \%$ & $0.6 \%$ \\
\hline & $\star 25$ to 34 & $30.2 \%$ & $69.8 \%$ & $87.0 \%$ & $13.0 \%$ & $19.9 \%$ & $55.2 \%$ & $17.4 \%$ & $7.3 \%$ & $0.0 \%$ & $0.2 \%$ \\
\hline & $\star 35$ to 44 & $31.3 \%$ & $68.7 \%$ & $87.7 \%$ & $12.3 \%$ & $14.3 \%$ & $58.8 \%$ & $15.2 \%$ & $10.6 \%$ & $0.3 \%$ & $0.7 \%$ \\
\hline & $\star 45$ to 54 & $28.7 \%$ & $71.3 \%$ & $86.7 \%$ & $13.3 \%$ & $12.3 \%$ & $54.5 \%$ & $18.1 \%$ & $13.9 \%$ & $0.2 \%$ & $1.0 \%$ \\
\hline & $\star 55$ to 59 & $28.5 \%$ & $71.5 \%$ & $88.0 \%$ & $12.0 \%$ & $14.3 \%$ & $58.8 \%$ & $15.2 \%$ & $10.6 \%$ & $0.3 \%$ & $0.7 \%$ \\
\hline & $\star 60$ to 64 & $29.5 \%$ & $70.5 \%$ & $89.5 \%$ & $10.5 \%$ & $9.2 \%$ & $49.7 \%$ & $15.5 \%$ & $24.2 \%$ & $0.2 \%$ & $1.3 \%$ \\
\hline & $\star 65$ to 69 & $22.0 \%$ & $78.0 \%$ & $88.6 \%$ & $11.4 \%$ & $8.0 \%$ & $36.5 \%$ & $20.3 \%$ & $33.4 \%$ & $0.9 \%$ & $0.9 \%$ \\
\hline & $\star 70$ and over & $11.7 \%$ & $88.3 \%$ & $81.7 \%$ & $18.3 \%$ & $5.4 \%$ & $24.9 \%$ & $19.3 \%$ & $48.6 \%$ & $0.9 \%$ & $0.8 \%$ \\
\hline \multirow[t]{2}{*}{ Sex } & $\star$ Female & $22.5 \%$ & $77.5 \%$ & $85.7 \%$ & $14.3 \%$ & $10.6 \%$ & $46.2 \%$ & $19.1 \%$ & $23.0 \%$ & $0.3 \%$ & $0.7 \%$ \\
\hline & $\star$ Male & $29.5 \%$ & $70.5 \%$ & $87.4 \%$ & $12.6 \%$ & $12.9 \%$ & $48.6 \%$ & $16.7 \%$ & $20.3 \%$ & $0.6 \%$ & $1.0 \%$ \\
\hline \multirow[t]{2}{*}{$\mathrm{FL}$} & $\star$ Yes & $39.5 \%$ & $60.5 \%$ & $93.1 \%$ & $6.9 \%$ & $18.8 \%$ & $54.2 \%$ & $15.2 \%$ & $11.1 \%$ & $0.4 \%$ & $0.4 \%$ \\
\hline & $\star$ No & $24.5 \%$ & $75.5 \%$ & $85.9 \%$ & $14.1 \%$ & $11.0 \%$ & $46.7 \%$ & $18.3 \%$ & $22.7 \%$ & $0.4 \%$ & $0.9 \%$ \\
\hline \multirow{5}{*}{ Inc } & $\star$ Less than $\$ 13,001$ & $17.1 \%$ & $82.9 \%$ & $73.2 \%$ & $26.8 \%$ & $8.1 \%$ & $37.9 \%$ & $21.9 \%$ & $29.9 \%$ & $0.9 \%$ & $1.2 \%$ \\
\hline & $\star \$ 13,001$ to $\$ 24,999$ & $14.6 \%$ & $85.4 \%$ & $77.0 \%$ & $23.0 \%$ & $8.8 \%$ & $38.7 \%$ & $19.0 \%$ & $31.8 \%$ & $0.8 \%$ & $0.8 \%$ \\
\hline & $\star \$ 25,000$ to $\$ 39,999$ & $22.4 \%$ & $77.6 \%$ & $88.3 \%$ & $11.7 \%$ & $11.9 \%$ & $49.7 \%$ & $16.8 \%$ & $20.7 \%$ & $0.2 \%$ & $0.6 \%$ \\
\hline & $\star \$ 40,000$ to $\$ 62,999$ & $28.9 \%$ & $71.1 \%$ & $93.1 \%$ & $6.9 \%$ & $12.8 \%$ & $53.0 \%$ & $17.8 \%$ & $15.8 \%$ & $0.2 \%$ & $0.5 \%$ \\
\hline & $\star \$ 63,000$ and over & $42.7 \%$ & $57.3 \%$ & $96.8 \%$ & $3.2 \%$ & $15.2 \%$ & $53.2 \%$ & $16.0 \%$ & $14.3 \%$ & $0.3 \%$ & $1.0 \%$ \\
\hline \multirow{5}{*}{ Edu } & $\star$ High school or less & $17.4 \%$ & $82.6 \%$ & $78.0 \%$ & $22.0 \%$ & $9.3 \%$ & $39.7 \%$ & $18.7 \%$ & $30.9 \%$ & $0.5 \%$ & $1.0 \%$ \\
\hline & $\star$ Some college, university without degree & $27.1 \%$ & $72.9 \%$ & $87.4 \%$ & $12.6 \%$ & $11.6 \%$ & $53.4 \%$ & $16.6 \%$ & $16.6 \%$ & $0.8 \%$ & $1.0 \%$ \\
\hline & $\star$ College, trade, vocational or technical school & $25.5 \%$ & $74.5 \%$ & $88.5 \%$ & $11.5 \%$ & $12.5 \%$ & $51.5 \%$ & $15.8 \%$ & $18.7 \%$ & $0.4 \%$ & $1.0 \%$ \\
\hline & $\star$ University undergraduate degree & $36.7 \%$ & $63.3 \%$ & $95.5 \%$ & $4.5 \%$ & $14.1 \%$ & $50.4 \%$ & $19.6 \%$ & $15.2 \%$ & $0.3 \%$ & $0.4 \%$ \\
\hline & $\star$ University graduate degree and over & $40.4 \%$ & $59.6 \%$ & $98.2 \%$ & $1.8 \%$ & $11.6 \%$ & $50.9 \%$ & $22.0 \%$ & $15.0 \%$ & $0.5 \%$ & $0.0 \%$ \\
\hline \multirow{8}{*}{ RRSPS } & $\star$ Less than $\$ 25,000$ & $28.0 \%$ & $72.0 \%$ & $93.7 \%$ & $6.3 \%$ & $14.1 \%$ & $55.5 \%$ & $16.7 \%$ & $12.8 \%$ & $0.4 \%$ & $0.6 \%$ \\
\hline & $\star \$ 25,000$ to under $\$ 50,000$ & $30.0 \%$ & $70.0 \%$ & $96.6 \%$ & $3.4 \%$ & $12.0 \%$ & $53.7 \%$ & $17.8 \%$ & $16.0 \%$ & $0.0 \%$ & $0.5 \%$ \\
\hline & $\star \$ 50,000$ to under $\$ 75,000$ & $33.8 \%$ & $66.2 \%$ & $98.6 \%$ & $1.4 \%$ & $10.4 \%$ & $52.4 \%$ & $17.0 \%$ & $18.8 \%$ & $0.7 \%$ & $0.7 \%$ \\
\hline & $\star \$ 75,000$ to under $\$ 100,000$ & $34.3 \%$ & $65.7 \%$ & $100.0 \%$ & $0.0 \%$ & $10.4 \%$ & $58.5 \%$ & $15.6 \%$ & $14.1 \%$ & $0 \%$ & $0 \%$ \\
\hline & $\star \$ 100,000$ to under $\$ 125,000$ & $39.0 \%$ & $61.0 \%$ & $97.3 \%$ & $2.7 \%$ & $13.4 \%$ & $45.8 \%$ & $15.7 \%$ & $22.7 \%$ & $0.9 \%$ & $1.4 \%$ \\
\hline & $\star \$ 125,000$ to under $\$ 200,000$ & $39.4 \%$ & $60.6 \%$ & $97.5 \%$ & $2.5 \%$ & $14.1 \%$ & $46.2 \%$ & $22.2 \%$ & $16.2 \%$ & $0.0 \%$ & $1.3 \%$ \\
\hline & $\star \$ 200,000$ to under $\$ 250,000$ & $44.9 \%$ & $55.1 \%$ & $98.7 \%$ & $1.3 \%$ & $13.0 \%$ & $52.7 \%$ & $17.8 \%$ & $15.8 \%$ & $0.0 \%$ & $0.7 \%$ \\
\hline & $\star \$ 250,000$ and over & $50.4 \%$ & $49.6 \%$ & $98.6 \%$ & $1.4 \%$ & $13.6 \%$ & $50.6 \%$ & $13.1 \%$ & $21.3 \%$ & $0.9 \%$ & $0.6 \%$ \\
\hline \multirow{6}{*}{$\mathrm{DL}$} & $\star$ Less than $\$ 50,000$ & $24.7 \%$ & $75.3 \%$ & $88.0 \%$ & $12.0 \%$ & $11.1 \%$ & $54.2 \%$ & $18.6 \%$ & $15.5 \%$ & $0.2 \%$ & $0.4 \%$ \\
\hline & $\star \$ 50,000$ to $\$ 99,999$ & $29.7 \%$ & $70.3 \%$ & $92.5 \%$ & $7.5 \%$ & $14.8 \%$ & $60.2 \%$ & $15.2 \%$ & $9.2 \%$ & $0.4 \%$ & $0.2 \%$ \\
\hline & $\star \$ 100,000$ to $\$ 149,999$ & $33.9 \%$ & $66.1 \%$ & $93.1 \%$ & $6.9 \%$ & $14.4 \%$ & $56.6 \%$ & $17.2 \%$ & $11.2 \%$ & $0.0 \%$ & $0.6 \%$ \\
\hline & $\star \$ 150,000$ to $\$ 199,999$ & $34.7 \%$ & $65.3 \%$ & $97.3 \%$ & $2.7 \%$ & $19.2 \%$ & $56.9 \%$ & $13.8 \%$ & $8.1 \%$ & $0.4 \%$ & $1.5 \%$ \\
\hline & $\star \$ 200,000$ to $\$ 249,999$ & $41.9 \%$ & $58.1 \%$ & $97.7 \%$ & $2.3 \%$ & $14.6 \%$ & $63.7 \%$ & $14.2 \%$ & $5.7 \%$ & $0.5 \%$ & $1.4 \%$ \\
\hline & $\star \$ 250,000$ or more & $37.6 \%$ & $62.4 \%$ & $97.7 \%$ & $2.3 \%$ & $22.6 \%$ & $51.4 \%$ & $16.5 \%$ & $7.4 \%$ & $0.7 \%$ & $1.4 \%$ \\
\hline
\end{tabular}

Note: FL means Financial Literacy, Inc means Income, Edu means Education, RRSPs mean Registered Retirement Savings Plans, 


\section{icaldilyme}

$3^{\text {rd }}$ International Conference on Advanced Research in

STOCKHOLM, SWEDEN BUSINESS, MANAGEMENT \& ECONOMICS

DL means Debts and Liabilities

Source: Author's compilation

Table 3. Do people have any retirement financial plans

\begin{tabular}{|c|c|c|c|c|c|c|c|c|c|c|}
\hline & \multirow{2}{*}{ Category } & \multicolumn{9}{|c|}{ Have Any Retirement Financial Plan } \\
\hline & & $\begin{array}{l}\text { Government } \\
\text { pension }\end{array}$ & $\begin{array}{l}\text { Workplace } \\
\text { pension }\end{array}$ & $\begin{array}{l}\text { Personal } \\
\text { pension }\end{array}$ & Mortgage & $\begin{array}{l}\text { Financial } \\
\text { Assets }\end{array}$ & $\begin{array}{l}\text { Non-Fin } \\
\text { Assets }\end{array}$ & Inheritance & Family & $\begin{array}{l}\text { Own } \\
\text { business }\end{array}$ \\
\hline \multirow{8}{*}{ Age } & $\star 18$ to 24 & $21.2 \%$ & $18.7 \%$ & $20.1 \%$ & $1.1 \%$ & $3.6 \%$ & $4.2 \%$ & $4.7 \%$ & $3.6 \%$ & $5.8 \%$ \\
\hline & $\star 25$ to 34 & $49.4 \%$ & $44.2 \%$ & $47.9 \%$ & $1.2 \%$ & $11.5 \%$ & $10.0 \%$ & $8.6 \%$ & $4.2 \%$ & $9.9 \%$ \\
\hline & $\star 35$ to 44 & $60.0 \%$ & $47.1 \%$ & $57.1 \%$ & $1.7 \%$ & $15.7 \%$ & $13.2 \%$ & $12.8 \%$ & $5.2 \%$ & $11.1 \%$ \\
\hline & $\star 45$ to 54 & $61.2 \%$ & $46.7 \%$ & $58.1 \%$ & $2.0 \%$ & $15.7 \%$ & $13.7 \%$ & $9.1 \%$ & $6.2 \%$ & $11.2 \%$ \\
\hline & $\star 55$ to 59 & $56.5 \%$ & $39.4 \%$ & $51.1 \%$ & $1.8 \%$ & $10.6 \%$ & $11.7 \%$ & $8.0 \%$ & $5.9 \%$ & $9.2 \%$ \\
\hline & $\star 60$ to 64 & $45.4 \%$ & $24.3 \%$ & $36.7 \%$ & $0.6 \%$ & $8.1 \%$ & $6.7 \%$ & $3.9 \%$ & $3.1 \%$ & $7.2 \%$ \\
\hline & $\star 65$ to 69 & $16.7 \%$ & $8.5 \%$ & $14.7 \%$ & $0.3 \%$ & $2.5 \%$ & $2.3 \%$ & $2.0 \%$ & $0.6 \%$ & $3.8 \%$ \\
\hline & $\star 70$ and over & $3.9 \%$ & $1.3 \%$ & $2.6 \%$ & $0.0 \%$ & $0.8 \%$ & $0.8 \%$ & $0.2 \%$ & $0.4 \%$ & $1.2 \%$ \\
\hline \multirow[t]{2}{*}{ Sex } & $\star$ Female & $37.9 \%$ & $28.0 \%$ & $34.2 \%$ & $0.8 \%$ & $7.5 \%$ & $7.6 \%$ & $6.0 \%$ & $4.5 \%$ & $6.5 \%$ \\
\hline & $\star$ Male & $42.4 \%$ & $31.3 \%$ & $40.0 \%$ & $1.4 \%$ & $11.1 \%$ & $8.8 \%$ & $6.7 \%$ & $2.7 \%$ & $8.7 \%$ \\
\hline \multirow[t]{2}{*}{$\mathrm{FL}$} & $\star$ Yes & $49.0 \%$ & $37.7 \%$ & $49.9 \%$ & $1.1 \%$ & $16.4 \%$ & $12.8 \%$ & $12.0 \%$ & $5.3 \%$ & $13.9 \%$ \\
\hline & $\star$ No & $39.2 \%$ & $28.8 \%$ & $35.8 \%$ & $1.1 \%$ & $8.5 \%$ & $7.8 \%$ & $5.8 \%$ & $3.5 \%$ & $7.0 \%$ \\
\hline \multirow{5}{*}{ Inc } & $\star$ Less than $\$ 13,001$ & $17.6 \%$ & $9.6 \%$ & $15.5 \%$ & $0.5 \%$ & $4.3 \%$ & $2.9 \%$ & $2.8 \%$ & $3.9 \%$ & $3.3 \%$ \\
\hline & $\star \$ 13,001$ to $\$ 24,999$ & $16.9 \%$ & $8.6 \%$ & $14.0 \%$ & $0.5 \%$ & $2.8 \%$ & $3.2 \%$ & $2.3 \%$ & $2.3 \%$ & $4.3 \%$ \\
\hline & $\star \$ 25,000$ to $\$ 39,999$ & $37.3 \%$ & $26.2 \%$ & $31.4 \%$ & $0.9 \%$ & $6.6 \%$ & $7.7 \%$ & $6.5 \%$ & $3.8 \%$ & $5.2 \%$ \\
\hline & $\star \$ 40,000$ to $\$ 62,999$ & $53.8 \%$ & $43.0 \%$ & $49.0 \%$ & $1.6 \%$ & $10.5 \%$ & $9.5 \%$ & $8.2 \%$ & $4.5 \%$ & $8.4 \%$ \\
\hline & $\star \$ 63,000$ and over & $67.2 \%$ & $53.9 \%$ & $68.0 \%$ & $1.8 \%$ & $20.0 \%$ & $15.8 \%$ & $10.7 \%$ & $3.8 \%$ & $15.2 \%$ \\
\hline \multirow{5}{*}{ Edu } & $\star$ High school or less & $27.5 \%$ & $17.5 \%$ & $23.2 \%$ & $0.7 \%$ & $5.5 \%$ & $5.3 \%$ & $3.6 \%$ & $2.7 \%$ & $4.7 \%$ \\
\hline & $\star$ Some college, university without degree & $38.2 \%$ & $29.2 \%$ & $36.6 \%$ & $1.7 \%$ & $9.5 \%$ & $7.6 \%$ & $7.4 \%$ & $3.8 \%$ & $7.8 \%$ \\
\hline & $\star$ College, trade, vocational or technical school & $45.2 \%$ & $34.4 \%$ & $41.0 \%$ & $1.3 \%$ & $9.5 \%$ & $9.4 \%$ & $6.3 \%$ & $4.2 \%$ & $7.4 \%$ \\
\hline & $\star$ University undergraduate degree & $51.3 \%$ & $40.8 \%$ & $51.2 \%$ & $1.2 \%$ & $12.9 \%$ & $10.1 \%$ & $9.6 \%$ & $4.3 \%$ & $9.9 \%$ \\
\hline & $\star$ University graduate degree and over & $53.5 \%$ & $41.0 \%$ & $53.7 \%$ & $1.1 \%$ & $16.7 \%$ & $12.3 \%$ & $11.4 \%$ & $4.6 \%$ & $15.6 \%$ \\
\hline \multirow{8}{*}{ RRSPs } & $\star$ Less than $\$ 25,000$ & $56.8 \%$ & $46.7 \%$ & $62.6 \%$ & $1.5 \%$ & $11.5 \%$ & $13.2 \%$ & $10.4 \%$ & $6.5 \%$ & $10.2 \%$ \\
\hline & $\star \$ 25,000$ to under $\$ 50,000$ & $54.9 \%$ & $39.9 \%$ & $63.1 \%$ & $0.8 \%$ & $13.1 \%$ & $12.4 \%$ & $10.3 \%$ & $3.1 \%$ & $8.2 \%$ \\
\hline & $\star \$ 50,000$ to under $\$ 75,000$ & $66.4 \%$ & $48.5 \%$ & $71.2 \%$ & $3.7 \%$ & $17.6 \%$ & $10.5 \%$ & $8.5 \%$ & $5.1 \%$ & $9.8 \%$ \\
\hline & $\star \$ 75,000$ to under $\$ 100,000$ & $60.0 \%$ & $45.2 \%$ & $70.4 \%$ & $1.5 \%$ & $20.0 \%$ & $17.0 \%$ & $11.1 \%$ & $4.4 \%$ & $8.9 \%$ \\
\hline & $\star \$ 100,000$ to under $\$ 125,000$ & $55.2 \%$ & $38.0 \%$ & $63.8 \%$ & $0.9 \%$ & $15.4 \%$ & $10.0 \%$ & $9.5 \%$ & $5.0 \%$ & $13.1 \%$ \\
\hline & $\star \$ 125,000$ to under $\$ 200,000$ & $54.2 \%$ & $37.0 \%$ & $63.0 \%$ & $2.1 \%$ & $20.6 \%$ & $10.1 \%$ & $9.7 \%$ & $5.5 \%$ & $14.3 \%$ \\
\hline & $\star \$ 200,000$ to under $\$ 250,000$ & $57.6 \%$ & $42.4 \%$ & $62.9 \%$ & $2.0 \%$ & $15.2 \%$ & $16.6 \%$ & $10.6 \%$ & $4.6 \%$ & $13.9 \%$ \\
\hline & $\star \$ 250,000$ and over & $55.6 \%$ & $28.7 \%$ & $64.5 \%$ & $1.1 \%$ & $20.1 \%$ & $11.6 \%$ & $9.9 \%$ & $2.8 \%$ & $20.4 \%$ \\
\hline \multirow{6}{*}{$\mathrm{DL}$} & $\star$ Less than $\$ 50,000$ & $43.2 \%$ & $33.7 \%$ & $38.1 \%$ & $1.0 \%$ & $9.3 \%$ & $7.7 \%$ & $7.4 \%$ & $4.3 \%$ & $7.1 \%$ \\
\hline & $\star \$ 50,000$ to $\$ 99,999$ & $58.7 \%$ & $45.4 \%$ & $54.6 \%$ & $1.5 \%$ & $12.5 \%$ & $12.0 \%$ & $7.5 \%$ & $4.3 \%$ & $11.0 \%$ \\
\hline & $\star \$ 100,000$ to $\$ 149,999$ & $57.6 \%$ & $42.7 \%$ & $53.5 \%$ & $1.9 \%$ & $14.7 \%$ & $14.7 \%$ & $12.2 \%$ & $4.7 \%$ & $11.9 \%$ \\
\hline & $\star \$ 150,000$ to $\$ 199,999$ & $61.2 \%$ & $48.7 \%$ & $57.8 \%$ & $1.9 \%$ & $15.6 \%$ & $16.3 \%$ & $10.3 \%$ & $4.9 \%$ & $14.1 \%$ \\
\hline & $\star \$ 200,000$ to $\$ 249,999$ & $65.9 \%$ & $55.0 \%$ & $68.2 \%$ & $2.3 \%$ & $18.2 \%$ & $16.4 \%$ & $13.2 \%$ & $6.4 \%$ & $11.4 \%$ \\
\hline & $\star \$ 250,000$ or more & $68.5 \%$ & $49.2 \%$ & $67.6 \%$ & $2.5 \%$ & $22.7 \%$ & $22.0 \%$ & $12.9 \%$ & $5.9 \%$ & $19.5 \%$ \\
\hline
\end{tabular}


Note: FL means Financial Literacy, Inc means Income, Edu means Education, RRSPs mean Registered Retirement Savings Plans, DL means Debts and Liabilities

Source: Author's compilation

Table 4 . The attitude to the safest place for university money

\begin{tabular}{|c|c|c|c|c|c|c|}
\hline & \multirow{2}{*}{ Category } & \multicolumn{5}{|c|}{ Safest place for university money } \\
\hline & & Corporate bonds & Mutual funds & A bank saving account & Lock in safe at home & Stock \\
\hline \multirow{8}{*}{ Age } & $\star 18$ to 24 & $3.15 \%$ & $6.94 \%$ & $80.76 \%$ & $8.20 \%$ & $0.95 \%$ \\
\hline & $\star 25$ to 34 & $2.30 \%$ & $10.57 \%$ & $78.18 \%$ & $8.54 \%$ & $0.41 \%$ \\
\hline & $\star 35$ to 44 & $6.42 \%$ & $13.99 \%$ & $72.71 \%$ & $5.28 \%$ & $1.61 \%$ \\
\hline & $\star 45$ to 54 & $4.86 \%$ & $17.09 \%$ & $69.84 \%$ & $4.95 \%$ & $3.27 \%$ \\
\hline & $\star 55$ to 59 & $5.42 \%$ & $18.23 \%$ & $71.48 \%$ & $3.97 \%$ & $0.90 \%$ \\
\hline & $\star 60$ to 64 & $5.48 \%$ & $13.96 \%$ & $71.20 \%$ & $4.77 \%$ & $4.59 \%$ \\
\hline & $\star 65$ to 69 & $5.72 \%$ & $15.58 \%$ & $71.79 \%$ & $3.35 \%$ & $3.55 \%$ \\
\hline & $\star 70$ and over & $6.15 \%$ & $13.18 \%$ & $72.63 \%$ & $4.25 \%$ & $3.80 \%$ \\
\hline \multirow[t]{2}{*}{ Sex } & $\star$ Female & $5.28 \%$ & $15.75 \%$ & $71.44 \%$ & $5.01 \%$ & $2.52 \%$ \\
\hline & $\star$ Male & $4.82 \%$ & $12.38 \%$ & $74.37 \%$ & $5.58 \%$ & $2.85 \%$ \\
\hline \multirow[t]{2}{*}{$\mathrm{FL}$} & $\star$ Yes & $4.90 \%$ & $10.45 \%$ & $80.38 \%$ & $2.77 \%$ & $1.49 \%$ \\
\hline & $\star$ No & $5.08 \%$ & $14.49 \%$ & $72.12 \%$ & $5.52 \%$ & $2.79 \%$ \\
\hline \multirow{5}{*}{ Inc } & $\star$ Less than $\$ 13,001$ & $5.32 \%$ & $12.66 \%$ & $72.28 \%$ & $6.46 \%$ & $3.29 \%$ \\
\hline & $\star \$ 13,001$ to $\$ 24,999$ & $4.78 \%$ & $15.59 \%$ & $69.79 \%$ & $5.65 \%$ & $4.19 \%$ \\
\hline & $\star \$ 25,000$ to $\$ 39,999$ & $5.05 \%$ & $15.38 \%$ & $70.91 \%$ & $5.77 \%$ & $2.88 \%$ \\
\hline & $\star \$ 40,000$ to $\$ 62,999$ & $4.79 \%$ & $14.89 \%$ & $72.83 \%$ & $5.13 \%$ & $2.35 \%$ \\
\hline & $\star \$ 63,000$ and over & $5.40 \%$ & $11.98 \%$ & $77.53 \%$ & $3.92 \%$ & $1.17 \%$ \\
\hline \multirow{5}{*}{ Edu } & $\star$ High school or less & $4.83 \%$ & $15.94 \%$ & $68.06 \%$ & $7.22 \%$ & $3.94 \%$ \\
\hline & $\star$ Some college, university without degree & $5.03 \%$ & $8.94 \%$ & $78.49 \%$ & $4.19 \%$ & $3.35 \%$ \\
\hline & $\star$ College, trade, vocational or technical school & $4.83 \%$ & $15.19 \%$ & $72.38 \%$ & $5.32 \%$ & $2.28 \%$ \\
\hline & $\star$ University undergraduate degree & $4.93 \%$ & $12.70 \%$ & $77.63 \%$ & $3.13 \%$ & $1.61 \%$ \\
\hline & $\star$ University graduate degree and over & $7.95 \%$ & $10.12 \%$ & $78.07 \%$ & $2.65 \%$ & $1.20 \%$ \\
\hline \multirow{9}{*}{ RRSPS } & $\star$ Less than $\$ 25,000$ & $4.20 \%$ & $17.08 \%$ & $70.83 \%$ & $5.12 \%$ & $2.76 \%$ \\
\hline & $\star \$ 25,000$ to under $\$ 50,000$ & $3.74 \%$ & $18.97 \%$ & $70.98 \%$ & $4.31 \%$ & $2.01 \%$ \\
\hline & $\star \$ 50,000$ to under $\$ 75,000$ & $6.23 \%$ & $12.82 \%$ & $76.19 \%$ & $3.66 \%$ & $1.10 \%$ \\
\hline & $\star \$ 75,000$ to under $\$ 100,000$ & $7.20 \%$ & $12.80 \%$ & $74.40 \%$ & $2.40 \%$ & $3.20 \%$ \\
\hline & $\star \$ 100,000$ to under $\$ 125,000$ & $6.34 \%$ & $13.66 \%$ & $73.66 \%$ & $2.93 \%$ & $3.41 \%$ \\
\hline & $\star \$ 125,000$ to under $\$ 200,000$ & $5.91 \%$ & $12.73 \%$ & $76.82 \%$ & $1.82 \%$ & $2.73 \%$ \\
\hline & $\star \$ 200,000$ to under $\$ 250,000$ & $11.81 \%$ & $12.50 \%$ & $74.31 \%$ & $1.39 \%$ & $0.00 \%$ \\
\hline & $\star \$ 250,000$ and over & $6.59 \%$ & $9.46 \%$ & $79.37 \%$ & $2.01 \%$ & $2.58 \%$ \\
\hline & $\star$ Less than $\$ 50,000$ & $4.90 \%$ & $14.95 \%$ & $71.63 \%$ & $5.60 \%$ & $2.93 \%$ \\
\hline
\end{tabular}




\section{icalulyme}

$3^{\text {rd }}$ International Conference on Advanced Research in

STOCKHOLM, SWEDEN BUSINESS, MANAGEMENT \& ECONOMICS

\begin{tabular}{|c|c|c|c|c|c|c|}
\hline \multirow[t]{5}{*}{$\mathrm{DL}$} & $\star \$ 50,000$ to $\$ 99,999$ & $4.95 \%$ & $15.57 \%$ & $73.11 \%$ & $4.25 \%$ & $2.12 \%$ \\
\hline & $\star \$ 100,000$ to $\$ 149,999$ & $7.25 \%$ & $17.22 \%$ & $71.30 \%$ & $3.32 \%$ & $0.91 \%$ \\
\hline & $\star \$ 150,000$ to $\$ 199,999$ & $5.24 \%$ & $13.71 \%$ & $76.61 \%$ & $2.82 \%$ & $1.61 \%$ \\
\hline & $\star \$ 200,000$ to $\$ 249,999$ & $2.44 \%$ & $11.22 \%$ & $83.41 \%$ & $1.95 \%$ & $0.98 \%$ \\
\hline & $\star \$ 250,000$ or more & $5.62 \%$ & $12.47 \%$ & $74.57 \%$ & $5.62 \%$ & $1.71 \%$ \\
\hline
\end{tabular}

Note: FL means Financial Literacy, Inc means Income, Edu means Education, RRSPs mean Registered Retirement Savings Plans,

DL means Debts and Liabilities

Source: Author's compilation

Table 5. Have people made use of any advice of the following financial products in the last 12 months

\begin{tabular}{|c|c|c|c|c|c|c|c|c|c|}
\hline \multirow{2}{*}{\multicolumn{2}{|c|}{ Category }} & \multicolumn{8}{|c|}{ Make use of any advice, free or paid, on any of the following financial products in the last 12 months } \\
\hline & & \multirow{2}{*}{$\begin{array}{c}\begin{array}{c}\text { Retirement } \\
\text { planning }\end{array} \\
5.6 \%\end{array}$} & \multirow{2}{*}{$\begin{array}{l}\begin{array}{l}\text { Children's } \\
\text { edu planning }\end{array} \\
3.1 \%\end{array}$} & \multirow{2}{*}{$\begin{array}{c}\begin{array}{c}\text { Estate } \\
\text { planning }\end{array} \\
1.1 \%\end{array}$} & \multirow{2}{*}{$\begin{array}{l}\text { Insurance } \\
14.2 \%\end{array}$} & \multirow{2}{*}{$\begin{array}{c}\begin{array}{c}\text { Tax } \\
\text { planning }\end{array} \\
6.7 \%\end{array}$} & \multirow{2}{*}{$\begin{array}{r}\begin{array}{r}\text { Financial } \\
\text { planning }\end{array} \\
17.0 \%\end{array}$} & \multirow{2}{*}{$\begin{array}{r}\text { Other } \\
0.0 \%\end{array}$} & \multirow{2}{*}{$\begin{array}{r}\text { No } \\
67.7 \%\end{array}$} \\
\hline \multirow{8}{*}{ Age } & $\star 18$ to 24 & & & & & & & & \\
\hline & $\star 25$ to 34 & $34.3 \%$ & $11.1 \%$ & $4.0 \%$ & $16.4 \%$ & $10.7 \%$ & $21.7 \%$ & $0.0 \%$ & $56.8 \%$ \\
\hline & $\star 35$ to 44 & $18.8 \%$ & $13.6 \%$ & $4.9 \%$ & $14.3 \%$ & $9.5 \%$ & $21.0 \%$ & $0.3 \%$ & $58.5 \%$ \\
\hline & $\star 45$ to 54 & $20.8 \%$ & $6.6 \%$ & $5.0 \%$ & $9.8 \%$ & $9.8 \%$ & $21.1 \%$ & $0.4 \%$ & $60.0 \%$ \\
\hline & $\star 55$ to 59 & $25.5 \%$ & $3.0 \%$ & $6.8 \%$ & $8.5 \%$ & $10.5 \%$ & $24.1 \%$ & $0.3 \%$ & $55.9 \%$ \\
\hline & $\star 60$ to 64 & $21.6 \%$ & $1.0 \%$ & $6.1 \%$ & $6.6 \%$ & $8.7 \%$ & $21.4 \%$ & $0.3 \%$ & $62.6 \%$ \\
\hline & $\star 65$ to 69 & $15.6 \%$ & $0.8 \%$ & $6.1 \%$ & $4.7 \%$ & $8.8 \%$ & $18.8 \%$ & $0.0 \%$ & $65.1 \%$ \\
\hline & $\star 70$ and over & $7.0 \%$ & $0.5 \%$ & $5.0 \%$ & $3.0 \%$ & $5.9 \%$ & $14.0 \%$ & $0.2 \%$ & $70.6 \%$ \\
\hline \multirow[t]{2}{*}{ Sex } & $\star$ Female & $16.3 \%$ & $5.4 \%$ & $5.2 \%$ & $9.1 \%$ & $8.3 \%$ & $19.4 \%$ & $0.2 \%$ & $62.0 \%$ \\
\hline & $\star$ Male & $16.3 \%$ & $5.4 \%$ & $4.8 \%$ & $9.4 \%$ & $9.4 \%$ & $20.0 \%$ & $0.2 \%$ & $62.4 \%$ \\
\hline \multirow[t]{2}{*}{$\mathrm{FL}$} & $\star$ Yes & $23.4 \%$ & $8.0 \%$ & $9.1 \%$ & $17.5 \%$ & $16.4 \%$ & $31.8 \%$ & $0.6 \%$ & $48.4 \%$ \\
\hline & $\star$ No & $15.7 \%$ & $5.1 \%$ & $4.7 \%$ & $8.6 \%$ & $8.2 \%$ & $18.6 \%$ & $0.2 \%$ & $63.4 \%$ \\
\hline \multirow{5}{*}{ Inc } & $\star$ Less than $\$ 13,001$ & $7.5 \%$ & $3.7 \%$ & $2.1 \%$ & $6.0 \%$ & $4.5 \%$ & $11.4 \%$ & $0.1 \%$ & $73.8 \%$ \\
\hline & $\star \$ 13,001$ to $\$ 24,999$ & $8.1 \%$ & $2.9 \%$ & $2.9 \%$ & $5.7 \%$ & $4.8 \%$ & $12.2 \%$ & $0.3 \%$ & $74.8 \%$ \\
\hline & $\star \$ 25,000$ to $\$ 39,999$ & $13.7 \%$ & $4.0 \%$ & $4.9 \%$ & $9.0 \%$ & $7.9 \%$ & $15.8 \%$ & $0.1 \%$ & $64.3 \%$ \\
\hline & $\star \$ 40,000$ to $\$ 62,999$ & $18.6 \%$ & $5.5 \%$ & $5.1 \%$ & $9.5 \%$ & $8.5 \%$ & $22.4 \%$ & $0.1 \%$ & $57.8 \%$ \\
\hline & $\star \$ 63,000$ and over & $30.8 \%$ & $10.3 \%$ & $9.3 \%$ & $15.1 \%$ & $16.8 \%$ & $34.2 \%$ & $0.4 \%$ & $44.0 \%$ \\
\hline \multirow{5}{*}{ Edu } & $\star$ High school or less & $9.5 \%$ & $2.4 \%$ & $2.8 \%$ & $4.9 \%$ & $5.1 \%$ & $11.7 \%$ & $0.2 \%$ & $72.9 \%$ \\
\hline & $\star$ Some college, university without degree & $14.5 \%$ & $3.8 \%$ & $5.0 \%$ & $8.3 \%$ & $7.8 \%$ & $16.4 \%$ & $0.0 \%$ & $63.7 \%$ \\
\hline & $\star$ College, trade, vocational or technical school & $19.1 \%$ & $5.2 \%$ & $5.1 \%$ & $9.9 \%$ & $8.8 \%$ & $20.3 \%$ & $0.2 \%$ & $60.2 \%$ \\
\hline & $\star$ University undergraduate degree & $21.4 \%$ & $9.7 \%$ & $7.1 \%$ & $15.0 \%$ & $12.7 \%$ & $29.0 \%$ & $0.3 \%$ & $52.3 \%$ \\
\hline & $\star$ University graduate degree and over & $27.9 \%$ & $12.3 \%$ & $11.6 \%$ & $14.3 \%$ & $19.5 \%$ & $38.6 \%$ & $0.2 \%$ & $39.5 \%$ \\
\hline \multirow{4}{*}{ RRSPS } & $\star$ Less than $\$ 25,000$ & $16.1 \%$ & $7.1 \%$ & $3.5 \%$ & $13.3 \%$ & $7.7 \%$ & $20.3 \%$ & $0.1 \%$ & $62.0 \%$ \\
\hline & $\star \$ 25,000$ to under $\$ 50,000$ & $23.5 \%$ & $8.8 \%$ & $4.6 \%$ & $11.3 \%$ & $9.0 \%$ & $25.8 \%$ & $0.3 \%$ & $56.7 \%$ \\
\hline & $\star \$ 50,000$ to under $\$ 75,000$ & $25.8 \%$ & $7.8 \%$ & $6.4 \%$ & $12.2 \%$ & $14.6 \%$ & $28.1 \%$ & $0.0 \%$ & $53.6 \%$ \\
\hline & $\star \$ 75,000$ to under $\$ 100,000$ & $32.6 \%$ & $8.1 \%$ & $8.1 \%$ & $9.6 \%$ & $11.1 \%$ & $33.3 \%$ & $0.7 \%$ & $43.0 \%$ \\
\hline
\end{tabular}




\section{icalinme}

$3^{\text {rd }}$ International Conference on Advanced Research in

STOCKHOLM, SWEDEN BUSINESS, MANAGEMENT \& ECONOMICS

\begin{tabular}{|c|c|c|c|c|c|c|c|c|c|}
\hline & $\star \$ 100,000$ to under $\$ 125,000$ & $31.2 \%$ & $7.2 \%$ & $8.6 \%$ & $12.7 \%$ & $13.6 \%$ & $34.4 \%$ & $0.0 \%$ & $46.2 \%$ \\
\hline & $\star \$ 125,000$ to under $\$ 200,000$ & $34.5 \%$ & $7.1 \%$ & $11.3 \%$ & $16.0 \%$ & $17.2 \%$ & $39.5 \%$ & $0.0 \%$ & $38.2 \%$ \\
\hline & $\star \$ 200,000$ to under $\$ 250,000$ & $39.7 \%$ & $13.2 \%$ & $11.3 \%$ & $14.6 \%$ & $23.8 \%$ & $45.7 \%$ & $2.0 \%$ & $33.8 \%$ \\
\hline & $\star \$ 250,000$ and over & $41.6 \%$ & $6.6 \%$ & $16.3 \%$ & $15.2 \%$ & $25.6 \%$ & $46.8 \%$ & $0.3 \%$ & $32.0 \%$ \\
\hline \multirow{6}{*}{$\mathrm{DL}$} & $\star$ Less than $\$ 50,000$ & $17.1 \%$ & $5.1 \%$ & $4.5 \%$ & $9.9 \%$ & $8.4 \%$ & $18.7 \%$ & $0.1 \%$ & $64.9 \%$ \\
\hline & $\star \$ 50,000$ to $\$ 99,999$ & $20.6 \%$ & $7.3 \%$ & $5.2 \%$ & $11.6 \%$ & $9.5 \%$ & $23.2 \%$ & $0.4 \%$ & $59.8 \%$ \\
\hline & $\star \$ 100,000$ to $\$ 149,999$ & $23.3 \%$ & $8.0 \%$ & $6.1 \%$ & $13.6 \%$ & $10.8 \%$ & $24.9 \%$ & $0.6 \%$ & $57.1 \%$ \\
\hline & $\star \$ 150,000$ to $\$ 199,999$ & $25.5 \%$ & $11.0 \%$ & $6.8 \%$ & $19.4 \%$ & $14.4 \%$ & $25.1 \%$ & $0.0 \%$ & $52.5 \%$ \\
\hline & $\star \$ 200,000$ to $\$ 249,999$ & $25.0 \%$ & $12.3 \%$ & $6.8 \%$ & $19.1 \%$ & $16.8 \%$ & $29.5 \%$ & $0.5 \%$ & $49.5 \%$ \\
\hline & $\star \$ 250,000$ or more & $23.1 \%$ & $13.2 \%$ & $7.5 \%$ & $16.3 \%$ & $15.0 \%$ & $28.1 \%$ & $0.7 \%$ & $51.7 \%$ \\
\hline
\end{tabular}

Note: FL means Financial Literacy, Inc means Income, Edu means Education, RRSPs mean Registered Retirement Savings Plans,

DL means Debts and Liabilities

Source: Author's compilation 